LA WAE NCE LWFAMCFI: WATIONAL LABOAATORY.

\title{
Alloy 22 Localized Corrosion Susceptibility In Aqueous Solutions Of Chloride And Nitrate Salts Of Sodium And Potassium At $110-150^{\circ} \mathrm{C}$
}

\section{FY05 SUMMARY REPORT}

S. Felker, P.D. Hailey, T. Lian, and K.J. Staggs

G. Gdowski, Compiler

Yucca Mountain Project

Lawrence Livermore National Laboratory

September 2006 


\section{Disclaimer}

This document was prepared as an account of work sponsored by an agency of the United States Government. Neither the United States Government nor the University of California nor any of their employees, makes any warranty, express or implied, or assumes any legal liability or responsibility for the accuracy, completeness, or usefulness of any information, apparatus, product, or process disclosed, or represents that its use would not infringe privately owned rights. Reference herein to any specific commercial product, process, or service by trade name, trademark, manufacturer, or otherwise, does not necessarily constitute or imply its endorsement, recommendation, or favoring by the United States Government or the University of California. The views and opinions of authors expressed herein do not necessarily state or reflect those of the United States Government or the University of California, and shall not be used for advertising or product endorsement purposes.

\section{Auspices}

This work was performed under the auspices of the U.S. Department of Energy by University of California, Lawrence Livermore National Laboratory under Contract W-7405-Eng-48. 


\section{CONTENTS}

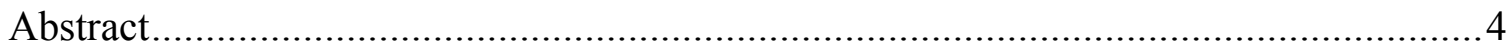

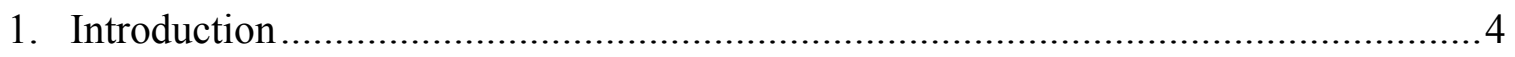

2. Technical Approach and Methods.................................................................6 6

2.1. Aqueous Solution Composition Determination; Chloride and Nitrate Solubility

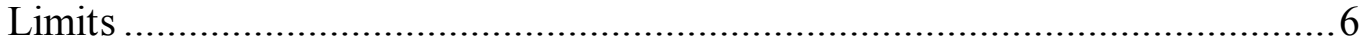

2.2. Corrosion Potential, $\mathrm{E}_{\text {corr }}($ Open Circuit Potential) ......................................... 9

2.3. $\mathrm{E}_{\text {crit }}$ Determination; Chloride + Nitrate solutions; $110^{\circ} \mathrm{C}$ to $150^{\circ} \mathrm{C} \ldots \ldots \ldots \ldots \ldots . . .10$

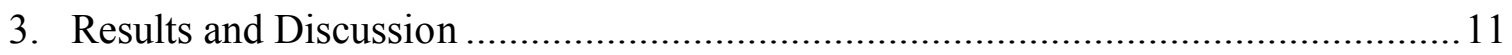

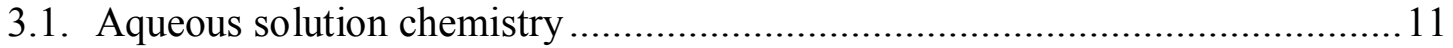

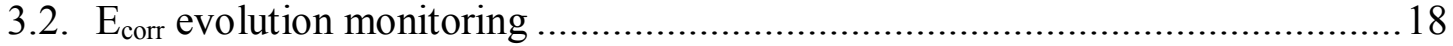

3.3. E $_{\text {crit }}$ determination with cyclic potentiodynamic polarization .......................... 19

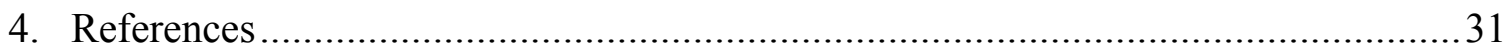




\section{Abstract}

Alloy 22 (a nickel-chromium-molybdenum-tungsten alloy) is being investigated for use as the outer barrier of waste containers for a high-level nuclear waste repository in the thick unsaturated zone at Yucca Mountain, Nevada. Experiments were conducted to assess crevice corrosion of Alloy 22 in de-aerated aqueous solutions of chloride and nitrate salts of potassium and sodium in the temperature range $110-150^{\circ} \mathrm{C}$ (some limited testing was also conducted at $90^{\circ} \mathrm{C}$ ). Electrochemical tests were run in neutral salt solutions without acid addition and others were run in salt solutions with an initial hydrogen ion concentration of $10^{-4}$ molal. The Alloy 22 specimens were weld prism specimens and de-aeration was performed with nitrogen gas. No evidence of crevice corrosion was observed in the range $125-150^{\circ} \mathrm{C}$.

In the 120 to $160^{\circ} \mathrm{C}$ temperature range, the anionic concentration of stable aqueous solutions is dominated by nitrate relative to chloride. At nominally $120^{\circ} \mathrm{C}$, the minimum nitrate to chloride ratio is about 4.5 , and it increases to about 22 at nominally $155^{\circ} \mathrm{C}$. The absence of localized corrosion susceptibility in these solutions is attributed to the known inhibiting effect of the nitrate anion. At $110^{\circ} \mathrm{C}$, aqueous solutions can have dissolved chloride in excess of nitrate. Localized corrosion was observed at nitrate to chloride ratios up to 1.0, the highest ratio tested. The extent of localized corrosion was confined to the crevice region of the samples, and was limited for nitrate to chloride ratios greater than or equal to 0.3 .

Aqueous solution chemistry studies indicate that nitrate to chloride ratios of less than 0.5 are possible for temperatures up to nominally $116^{\circ} \mathrm{C}$. However, the exact upper temperature limit is unknown and no electrochemical testing was done at these temperatures. Limited comparison between $8 \mathrm{~m} \mathrm{Cl}$ aqueous solutions of $\mathrm{Na}+\mathrm{K}$ on the one hand and $\mathrm{Ca}$ on the other indicated similar electrochemical $\mathrm{E}_{\text {crit }}$ values and similar morphology of attack, again limited to the crevice region. However, the $24 \mathrm{hr} \mathrm{E}_{\text {corr }}$ value was higher for the $\mathrm{Ca}$ based solution; this is probably due to the higher acidity of this solution $\left(\mathrm{Ca}^{2+}\right.$ is slightly hydrolyzing). Intermediate-term corrosion potential ( $\left.\mathrm{E}_{\text {corr }}\right)$ measurements indicate that moderately acidic conditions are required to achieve elevated $\mathrm{E}_{\text {corr }}$ values.

\section{Introduction}

This report addresses possible crevice corrosion that might occur on the waste package outer barrier (comprised of Alloy 22) in a high-level waste repository in the thick unsaturated zone at Yucca Mountain, Nevada. In this non-pressurized environment, aqueous solutions may form and stably exist above the nominal boiling point of water due to high salt content (e.g., BSC 2004). The majority of the aqueous solutions that are predicted to form on the waste packages due to dust deliquescence consists of chloride and nitrate salts of sodium and potassium. Recent work indicates that deliquescence of 
these salt mixtures can occur at temperatures in excess of $180^{\circ} \mathrm{C}$ [Rard 2004; Carroll et al 2005b]. Hence, understanding the degradation of Alloy 22 in these environments is necessary for the long-term prediction of waste package integrity.

Previous studies have shown that nitrate is an effective inhibitor of localized corrosion of corrosion resistant metal alloys [e.g. Brossia and Kelly 1998, Ilevbare et al. 2005]. This has been demonstrated for Alloy 22 in the temperature range 60 to $100^{\circ} \mathrm{C}$ for aqueous solutions of 1, 3.5 and 6 molal $\mathrm{Cl}$ [Ilevbare et al. 2005]. In the Ilevbare et al. study, localized corrosion inhibition was observed at $60^{\circ} \mathrm{C}$ with nitrate to chloride ratio of 0.15 and at $100^{\circ} \mathrm{C}$ with a ratio of 0.5

\section{Aqueous solution characteristics}

Carroll et al. [2005b] showed deliquescence of the $\mathrm{NaCl}+\mathrm{NaNO}_{3}+\mathrm{KNO}_{3}$ solids mixture occurring at temperatures up to at least $180^{\circ} \mathrm{C}$. Carroll et al. [2005a] measured a maximum boiling point (BP) of $135^{\circ} \mathrm{C}$ for the saturated $\mathrm{NaCl}+\mathrm{KNO}_{3}$ aqueous solution. BPs were also determined for non-saturated solutions (and similar data were also collected in the present study.) In addition, Carroll et al. [2005a] measured a maximum $\mathrm{BP}$ of $155^{\circ} \mathrm{C}$ for an equimolar mixture of nearly saturated $\mathrm{NaNO}_{3}+\mathrm{KNO}_{3}$ aqueous salt solution and a maximum $\mathrm{BP}$ in excess of $180^{\circ} \mathrm{C}$ for the saturated $\mathrm{NaCl}+\mathrm{NaNO}_{3}+\mathrm{KNO}_{3}$ salt solution.

Aqueous solution composition dependence on fixed relative humidity $(\mathrm{RH})$ for the $\mathrm{NaCl}$ $+\mathrm{KNO}_{3}$ system was obtained by Carroll et al. [2005a] at 90 and $120^{\circ} \mathrm{C}$. At $90^{\circ} \mathrm{C}$ chloride-only (i.e., no nitrate) solutions are possible, however at $120^{\circ} \mathrm{C}$ stable chloride solutions must also contain nitrate. The minimum nitrate to chloride ratio occurs at the maximum RH (which depends on the temperature and the total pressure). This ratio at $120^{\circ} \mathrm{C}$ is approximately 3 , with $\mathrm{NO}_{3}$ and $\mathrm{Cl}$ concentrations at 19 and 6 molal, respectively.

More recently Carroll et al. [2005b] have investigated the aqueous solution composition dependence on $\mathrm{RH}$ for the $\mathrm{NaCl}+\mathrm{KNO}_{3}+\mathrm{NaNO}_{3}$ aqueous salt mixture at $120^{\circ} \mathrm{C}$. For this system, the minimum nitrate to chloride ratio occurs at a measured $\mathrm{RH}$ of nominally $50 \%$ and is approximately equal to 5 with $\mathrm{NO}_{3}$ and $\mathrm{Cl}$ concentrations at 25 and 5 molal, respectively.

This present work builds on these previous studies and obtains composition characteristics of aqueous solutions of nitrate and chloride salts of potassium and sodium in the temperature range 110 to $160^{\circ} \mathrm{C}$. In particular, the focus of these studies is to determine the maximum amount of chloride that is soluble in these high temperature solutions because of known aggressiveness of chloride for inducing localized corrosion. Subsequent corrosion studies are conducted in test solutions based on these aqueous solution chemistry studies. 


\section{Corrosion}

Corrosion studies have shown that nitrate is an effective inhibitor of localized corrosion of corrosion resistant metal alloys [Brossia and Kelly 1998, Ilevbare et al. 2005]. LLNL has shown that nitrate is an effective inhibitor of chloride induced localized corrosion of Alloy 22 in the temperature range $60-100^{\circ} \mathrm{C}$ and for concentrations of $1,3.5$ and 6 molal $\mathrm{Cl}$ [Ilevbare et al. 2005]. Localized corrosion inhibition was observed at $60^{\circ} \mathrm{C}$ with nitrate to chloride ratio of 0.15 and at $100^{\circ} \mathrm{C}$ with a ratio of 0.5 .

Previous studies have indicated that nitrate ions can significantly increase the open circuit potential ( $\mathrm{E}_{\text {corr, }}$ corrosion potential) of Alloy 22. The nitrate containing aqueous conditions that lead to elevated $\mathrm{E}_{\text {corr }}$ are temperatures greater than $120^{\circ} \mathrm{C}$ and moderately acidic conditions $(<\mathrm{pH} 3)$. In addition, the nitrate to chloride ratio in the aqueous solutions may also have an effect on $\mathrm{E}_{\text {corr, }}$ with higher ratios typically resulting in higher $\mathrm{E}_{\text {corr }}$ values.

\section{Technical Approach and Methods}

\subsection{Aqueous Solution Composition Determination; Chloride and Nitrate Solubility Limits}

In the present work, aqueous solution compositions in the temperature range 110 to $160^{\circ} \mathrm{C}$ were determined for solutions of $\mathrm{NaCl}, \mathrm{KCl}, \mathrm{NaNO}_{3}$, and $\mathrm{KNO}_{3}$. For solutions where chloride can dominate the solution composition, maximum nitrate solubility in a solution of a fixed chloride concentration was determined. These solutions are limited to temperatures less than about $116^{\circ} \mathrm{C}$ because of the temperature stability limitations of chloride dominated solutions. For solutions in which nitrate dominates the solutions, the maximum amount of soluble chloride was determined. These solutions can exist at much higher temperatures because of the very high boiling points of the mixed nitrate salt solutions. Solution compositions are limited to those containing sodium and potassium as cations, since the majority of predicted aqueous solution compositions on the waste packages from seepage and dust deliquescence do not contain significant amounts of calcium or magnesium cations.

Literature data indicates that for mixtures of $\mathrm{NaCl}$ and $\mathrm{KCl}$ the maximum chloride solubility occurs for nearly equimolar solutions (see green highlighted rows in Table 1) [Linke 1965 p. 147]. It is assumed that this relationship also holds in aqueous solutions of nitrate and chloride, that is, maximum chloride concentrations occur in solutions where sodium and potassium cations are equal in molar concentration. No experimental verification of this assumption in nitrate containing solutions was performed.

Equimolar $\mathrm{KNO}_{3}$ and $\mathrm{NaNO}_{3}$ aqueous solutions are used extrapolating the assumption that maximum anion concentrations can be obtained in solutions of equimolar $\mathrm{Na}+\mathrm{K}$, as was the case for chloride (see Table 1). No verification of this assumption for chloride in 
nitrate dominated solutions was performed, however literature data does indicate that near maximum anion concentration in nitrate only solutions for equimolar $\mathrm{K}+\mathrm{Na}$ [see Linke 1965 p. 263].

In addition, Carroll et al. [2005a] demonstrated that a saturated aqueous solution with equal parts of potassium and sodium nitrate had a boiling point near the maximum for the $\mathrm{Na}-\mathrm{K}-\mathrm{NO}_{3}-\mathrm{Cl}$ system. Hence using equimolar nitrate solutions facilitates investigating solution composition characteristics for a large range of temperatures.

Table 1. Chloride solubility in aqueous salt solution of $\mathrm{NaCl}$ and $\mathrm{KCl}$ at $100^{\circ} \mathrm{C}$. [Linke 1965 p. 147].

\begin{tabular}{|c|c|c|c|c|c|}
\hline $\begin{array}{c}\text { gms/100 gms } \\
\text { saturated solution }\end{array}$ & \multicolumn{2}{|c|}{ molal } & \multicolumn{2}{c}{} \\
\cline { 1 - 3 } $\mathrm{KCl}$ & $\mathrm{NaCl}$ & $\mathrm{KCl}$ & $\mathrm{NaCl}$ & Solids & $\begin{array}{c}\text { Total Cl } \\
\text { molal }\end{array}$ \\
\hline 35.69 & 0 & 7.44 & 0.00 & $\mathrm{KCl}$ & 7.44 \\
\hline 30.4 & 6.3 & 6.44 & 1.70 & $\mathrm{KCl}$ & 8.14 \\
\hline 29.95 & 6.48 & 6.32 & 1.74 & $\mathrm{KCl}$ & 8.06 \\
\hline 27.7 & 9.43 & 5.91 & 2.57 & $\mathrm{KCl}$ & 8.48 \\
\hline 25 & 12.5 & 5.36 & 3.42 & $\mathrm{KCl}$ & 8.79 \\
\hline 24.88 & 12.69 & 5.35 & 3.48 & $\mathrm{KCl}$ & 8.82 \\
\hline 22.4 & 15.5 & 4.84 & 4.27 & $\mathrm{KCl}$ & 9.11 \\
\hline 22.2 & 15.9 & 4.81 & 4.40 & $\mathrm{KCl}+\mathrm{NaCl}$ & 9.21 \\
\hline 21.68 & 16.9 & 4.73 & 4.71 & $\mathrm{KCl}+\mathrm{NaCl}$ & 9.44 \\
\hline 19.12 & 18.12 & 4.09 & 4.94 & $\mathrm{NaCl}$ & 9.03 \\
\hline 19 & 17.7 & 4.03 & 4.78 & $\mathrm{NaCl}$ & 8.81 \\
\hline 10.25 & 22.57 & 2.05 & 5.75 & $\mathrm{NaCl}$ & 7.80 \\
\hline 0 & 28 & 0.00 & 6.65 & $\mathrm{NaCl}$ & 6.65 \\
\hline
\end{tabular}

It is acknowledged that the present study is not a thorough investigation of aqueous solutions of $\mathrm{NaCl}, \mathrm{KCl}, \mathrm{NaNO}_{3}$, and $\mathrm{KNO}_{3}$ in the temperature range 110 to $160^{\circ} \mathrm{C}$. However, the intent of the investigation was to determine near-maximum amounts of chlorides that are soluble in high temperature nitrate dominated solutions and based on literature data, that is thought to occur in solutions with equimolar amounts of $\mathrm{Na}$ and $\mathrm{K}$.

\section{Methodology}

Two approaches were taken to determine solubility limitations.

- A base chloride solution was made of equimolar $\mathrm{NaCl}$ and $\mathrm{KCl}$. Then dry salts equivalent to 0.5 molal increments of $\mathrm{KNO}_{3}$ and $\mathrm{NaNO}_{3}$ were added in an alternating order. The additions were continued until the solubility limit was reached.

- A base nitrate solution was prepared of equimolar $\mathrm{NaNO}_{3}$ and $\mathrm{KNO}_{3}$. Then dry salts equivalent to 0.5 molal increments amounts of $\mathrm{KCl}$ and $\mathrm{NaCl}$ were added in an alternating order. The additions were continued until the solubility limit was reached. 
The concentration of added salt was determined from the weight of the salt, molecular weight of the salts and the initial weight of water in the test cell. Because of the very strong temperature dependence of the nitrate salt solubility, the initial test solutions were made at elevated temperatures. Then incremental amounts of salt were added with a concurrent temperature elevation until the desired composition was reached.

To ensure that the maximum solubility was obtained in the chloride nitrate mixtures, the solutions were typically kept within approximately $4^{\circ} \mathrm{C}$ of their boiling point, which was measured after the addition of salt. After each addition of salt, the solution was kept near its boiling temperature until all the salt had dissolved. If the salt did not fully dissolve after several hours, the salt concentration just before the last addition was noted as the effective solubility limit.

A solution was also prepared to find the maximum solubility in a nitrate only solution $\left(\mathrm{KNO}_{3}\right.$ and $\left.\mathrm{NaNO}_{3}\right)$. This test was started at 100 molal total nitrate, and 1 molal equivalents of dry salts of nitrates were incrementally added until the nitrates could no longer dissolve into the solution. The boiling point of this solution was measured. Similarly, the boiling point of a saturated solution of equimolar $\mathrm{KCl}$ and $\mathrm{NaCl}$ was also determined.

\section{$\underline{\text { Test Apparatus }}$}

Solutions were placed in one-liter glass cells inside a heating mantle that was deep enough that the level of solution was completely inside the heater (to help minimize salt precipitation at the gas-solution interface). Water losses were reduced with a condenser that was cooled by water at nominally $8^{\circ} \mathrm{C}$. The thermocouple was connected to a control unit that set and monitored the desired temperature. A nitrogen bubbling tube was extended into the solution and the flow of gas was kept at around $100 \mathrm{~cm}^{3} / \mathrm{min}$ in order to mix the solution and to maintain slightly elevated pressure inside the vessel so as to minimize back diffusion of laboratory air. Figure 1 is a picture of the test apparatus.

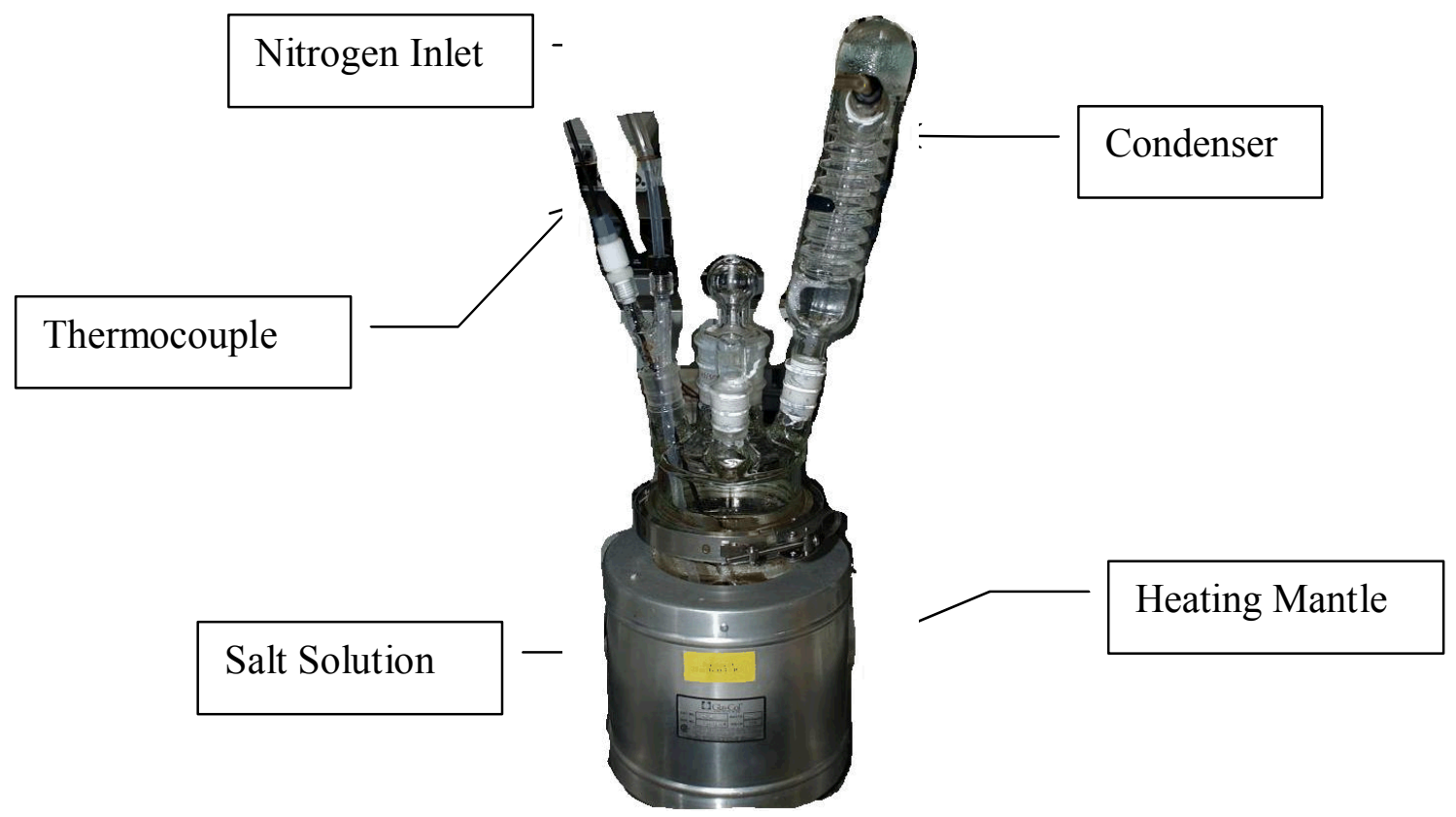

Figure 1. Experimental setup for aqueous solution chemistry testing. 


\subsection{Corrosion Potential, $E_{c o r r}$ (Open Circuit Potential)}

The following electrochemical tests related to $\mathrm{E}_{\text {corr }}$ were performed:

- monitoring of corrosion potential $\mathrm{E}_{\text {corr }}$ evolution as a function of time

- polarization resistance measurements during $\mathrm{E}_{\text {corr }}$ evolution

- electrochemical impedance spectroscopy during $\mathrm{E}_{\mathrm{corr}}$ evolution.

A three-electrode technique was used to conduct the electrochemical tests in a Pyrex corrosion cell containing a working electrode, an auxiliary electrode, and a Luggin capillary connected to a suitable reference electrode $\left(\mathrm{Ag} / \mathrm{AgCl}\right.$ or $\left.\mathrm{Hg} / \mathrm{Hg}_{2} \mathrm{Cl}_{2}\right)$. Carbon dioxide scrubbed air was purged through a dispenser immersed in the solution, applying a controlled flow. A condenser was used to avoid excessive losses of fluid due to evaporation of test solution. Also, a special designed water-jacketed Luggin probe maintained the reference electrode at or near room temperature. A controlledtemperature, heating mantle was used to maintain the test temperature at the desired value. Specimens were cleaned sequentially with distilled water, hexane, acetone, and methanol (or ethanol) prior to testing or as otherwise noted. Monitoring of the test specimen corrosion potential, $\mathrm{E}_{\text {corr, }}$ was performed using Gamry potentiostats controlled by Gamry Framework Software.

The following ASTM procedures were used as guidelines for performing the electrochemical testing.

ASTM G 5 Standard Reference Test Method for Making Potentiostatic and Potentiodynamic Anodic Polarization Measurements

ASTM G 48 Standard Test Methods for Pitting and Crevice Corrosion Resistance of Stainless Steels and Related Alloys by Use of Ferric Chloride Solution

ASTM G 59 Standard Test Method for Conducting Potentiodynamic Polarization Resistance Measurements

ASTM G 106 Standard Practice for Verification of Algorithm and Equipment for Electrochemical Impedance Measurements

In addition to monitoring the $\mathrm{E}_{\text {corr }}$ evolution with time, polarization resistance was performed periodically in order to obtain instantaneous corrosion (dissolution) rates, and electrochemical impedance spectroscopy (EIS) was performed in order to characterize the evolving oxide film. Obtaining these three complementary parameters should give a good indication of when the $\mathrm{E}_{\text {corr }}$ values have obtained steady state for a particular set of environmental conditions.

Non-welded Alloy 22 prism specimens were used in this testing. The creviced area on the specimens was minimal; limited to the mounting rod washer. Carbon dioxide scrubbed laboratory air was bubbled through the test solutions. The $\mathrm{CO}_{2}$ was removed from the air 
in order to keep steady-state hydrogen ion concentrations; the $\mathrm{CO}_{2}$ level in the laboratory air is not controlled or monitored. The acid test solutions were included in order to investigate conditions where $\mathrm{E}_{\text {corr }}$ is expected to obtain elevated values. The oxidizing effect of nitrate is accelerated at low $\mathrm{pH}$. Solutions designated as neutral are those with no acid addition and purge gas is carbon dioxide scrubbed air.

Only a very limited number of tests were performed at under very acidic conditions because of health and safety concerns with acid gas volatility. Methods to remove the acid gases that evolve during set up and testing are presently being investigated.

\section{3. $E_{\text {crit }}$ Determination; Chloride + Nitrate solutions; $110^{\circ} \mathrm{C}$ to $150^{\circ} \mathrm{C}$}

The electrochemical cyclic potentiodynamic polarization (CPP) procedure was used to determine $\mathrm{E}_{\text {crit }}$ values. CPP electrochemical tests were used to identify the breakdown potentials, the potential at which passivity is lost on the forward scan, and the crevice repassivation potentials, the potential below which localized corrosion initiation susceptibility is considered unlikely. The breakdown potential is reported as E20, the potential on the forward scan at which the anodic current density reaches $20 \times 10^{-6}$ $\mathrm{amps} / \mathrm{cm}^{2}$. The repassivation potential is reported as the potential (ER1) at which the current density is about $1 \mu \mathrm{A} / \mathrm{cm}^{2}$ on the reverse scan.

Cyclic potentiodynamic polarization (CPP) is a standard electrochemical procedure for determining electrochemical parameters relevant to corrosion. Several ASTM procedures listed are used as guidelines. The CPP testing was performed with the Gamry potentiostat and controlled with Gamry Framework Software.

A limited number of potentiostatic tests were also performed as confirmation that crevice initiation can occur at potentials near the repassivation potential. Potentiostatic testing was performed at potentials above the crevice repassivation potential as determined from the CPP. The ER1 potentials, as defined above, were used as the crevice repassivation potential.

\section{$\underline{\text { Test Apparatus }}$}

A three-electrode technique was used to conduct the electrochemical tests in a Pyrex corrosion cell which contained a working electrode (prism crevice assembly), graphite counter or platinum electrode, and a Luggin capillary connected to a suitable reference electrode $\left(\mathrm{Ag} / \mathrm{AgCl}\right.$ or $\mathrm{Hg} / \mathrm{Hg}_{2} \mathrm{Cl}_{2}$ ). Inert gas was purged through a dispenser immersed in the solution with a controlled flow. A condenser was used to avoid excessive evaporation of test solution. Also, a special designed water-jacketed Luggin probe maintained the reference electrode at or near room temperature. After polishing, specimens were cleaned sequentially with distilled water, hexane, acetone, and methanol (or ethanol) prior to testing or as otherwise noted in test data sheets. A controlled temperature heating mantle was used to maintain the test temperature at the desired value. 
The following ASTM procedures were used as guidelines for performing the electrochemical testing.

ASTM G 5 Standard Reference Test Method for Making Potentiostatic and Potentiodynamic Anodic Polarization Measurements

ASTM G 48 Standard Test Methods for Pitting and Crevice Corrosion Resistance of Stainless Steels and Related Alloys by Use of Ferric Chloride Solution

ASTM G 59 Standard Test Method for Conducting Potentiodynamic Polarization Resistance Measurements

ASTM G 61 Standard Test Method for Conducting Cyclic Potentiodynamic Polarization Measurements for Localized Corrosion Susceptibility of Iron-, Nickel-, or Cobalt-Based Alloys

ASTM G 106 Standard Practice for Verification of Algorithm and Equipment for Electrochemical Impedance Measurements

Post-test cleaning was performed as appropriate, as determined by specimen examination. The post-test specimens were initially examined visually, then by microscopic evaluation to detect the presence or absence of localized corrosion.

As with the measurement of $\mathrm{E}_{\text {corr }}$, aqueous solutions are limited to those obtainable using salts containing sodium $(\mathrm{Na})$ and potassium $(\mathrm{K})$, and not salts of calcium $(\mathrm{Ca})$ and magnesium $(\mathrm{Mg})$. These electrochemical tests were run in de-aerated solutions using nitrogen gas as the purge gas.

Several tests were to have been performed in autoclaves. The use of autoclaves was necessary for a number of reasons, such as the boiling points of the test solutions are exceeded at normal atmospheric pressure or the solution composition is near the solubility limit at the test temperature. These tests were to be performed in order to extend the $\mathrm{E}_{\text {crit }}$ determination to the limits of stability (boiling point under atmospheric pressure) of the solution composition. (Tests at or near boiling conditions are experimentally difficult to perform, hence, the use of an autoclave simplifies the testing). The electrochemical autoclaves were ordered soon after funding for these studies became available. Unfortunately, autoclaves were not delivered until late September 2005 and there were several safety issues with the autoclaves in the as-delivered condition.

\section{Results and Discussion}

\subsection{Aqueous solution chemistry}

The aqueous solution chemistry studies were as follows: 
- For temperatures greater than $120^{\circ} \mathrm{C}$, the focus was to determine the maximum concentration of chloride for a given nitrate concentration, with the concurrent determination of the corresponding boiling point.

- For temperatures less than $116^{\circ} \mathrm{C}$, the focus was to determine the maximum concentration of nitrate for a given chloride concentration, again with the concurrent determination of the corresponding boiling point.

- The maximum solubility of chloride-only and nitrate-only solutions were also determined, along with the associated boiling points

Tables 2 and 3 list the parameters that were used in the testing. Tables 4 and 5 list the test results. The methodology of obtaining the uncertainties of the points in Figures 2-6 is described in Appendix A. The results of the uncertainty calculations are also listed there.

Table 2. Test parameters for determination of chloride solubility in nitrate solutions.

\begin{tabular}{|c|c|c|c|c|c|}
\hline $\begin{array}{c}\text { Nitrate } \\
\text { molality }\end{array}$ & \multicolumn{2}{|c|}{ Initial Salt (g) } & $\begin{array}{c}\text { Initial DI } \\
\text { water (g) }\end{array}$ & $\begin{array}{c}\text { Increment (g) equal to } \\
0.5 \text { molal Cl}^{-1}\end{array}$ \\
\hline & $\mathrm{KNO}_{3}$ & $\mathrm{NaNO}_{3}$ & & $\mathrm{KCl}$ & $\mathrm{NaCl}$ \\
\hline 25 & 379.2 & 318.7 & 300 & 11.1 & 8.7 \\
\hline 42 & 530.8 & 446.2 & 250 & 9.3 & 7.3 \\
\hline 50 & 631.9 & 531.2 & 250 & 9.3 & 7.3 \\
\hline 75 & 568.7 & 478.1 & 150 & 5.6 & 4.4 \\
\hline 85 & 644.6 & 541.8 & 150 & 5.6 & 4.4 \\
\hline 100 & 606.7 & 509.9 & 120 & 4.5 & 3.5 \\
\hline
\end{tabular}

Table 3. Test parameters for determination of nitrate solubility in chloride solutions.

\begin{tabular}{|c|c|c|c|c|c|}
\hline $\begin{array}{c}\text { Chloride } \\
\text { molality }\end{array}$ & \multicolumn{2}{|c|}{ Initial Salt (g) } & $\begin{array}{c}\text { Initial DI } \\
\text { water (g) }\end{array}$ & $\begin{array}{c}\text { Increment (g) equal to } \\
0.5 \text { molal } \mathrm{NO}_{3}{ }^{-}\end{array}$ \\
\hline & $\mathrm{KCl}$ & $\mathrm{NaCl}$ & & $\mathrm{KNO}_{3}$ & $\mathrm{NaNO}_{3}$ \\
\hline 6 & 89.5 & 70.1 & 400 & 20.2 & 17.0 \\
\hline 8 & 119.3 & 93.5 & 400 & 20.2 & 17.0 \\
\hline 9 & 167.8 & 131.5 & 500 & 25.3 & 21.2 \\
\hline
\end{tabular}


Table 4. Boiling points of nitrate chloride solutions. Nitrate fixed and chloride variable. [DTN LL051100623121.054].

\begin{tabular}{|c|c|c|c|c|c|c|c|c|c|c|c|c|}
\hline & & \multicolumn{11}{|c|}{ Boiling Points $\left({ }^{\circ} \mathrm{C}\right)$} \\
\hline & & \multicolumn{11}{|c|}{ Chloride molality } \\
\hline & & 0 & 0.5 & 1 & 1.5 & 2 & 2.5 & 3 & 3.5 & 4 & 4.5 & 5 \\
\hline \multirow{13}{*}{ 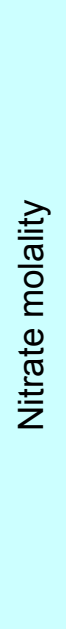 } & 25 & 118.7 & & 119.9 & & 120.3 & & 121.8 & & 121.8 & & 122.3 \\
\hline & 42 & & & 128.0 & & & & & & & & \\
\hline & 50 & 131.3 & & 133.1 & & 133.0 & & 134.9 & & 134.7 & & \\
\hline & 75 & 141.3 & & 141.7 & 142.3 & 142.3 & 142.8 & 144.7 & 145.2 & 145.2 & & \\
\hline & 85 & 145.0 & & & & 146.8 & 149.7 & 147.3 & & 147.1 & 148.0 & \\
\hline & 100 & 150.5 & 150.2 & 152.4 & 154.5 & 155.2 & 156.3 & 155.2 & 158.3 & 160.3 & 160.9 & \\
\hline & 111 & 154.9 & & & & & & & & & & \\
\hline & 30 & 121.2 & & & & & & & & & & \\
\hline & 45 & 129.5 & & & & & & & & & & \\
\hline & 60 & 136.4 & & & & & & & & & & \\
\hline & 67.5 & 139.1 & & & & & & & & & & \\
\hline & 75 & 143.6 & & & & & & & & & & \\
\hline & 90 & 151.8 & & & & & & & & & & \\
\hline
\end{tabular}

Table 5. Boiling points of nitrate chloride solutions. Chloride fixed and nitrate variable. [DTN LL051100623121.054].

\begin{tabular}{|c|c|c|c|c|c|}
\hline & \multicolumn{4}{|c|}{ Boiling Points $\left({ }^{\circ} \mathrm{C}\right)$} \\
\hline & & \multicolumn{4}{|c|}{ Nitrate molality } \\
\hline & & 0 & 3 & 6 & 18 \\
\hline \multirow{3}{*}{ 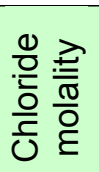 } & 6 & & & & 115.0 \\
\hline & 8 & & & 116.5 & \\
\hline & 9 & 111.6 & 115.0 & & \\
\hline
\end{tabular}


In Figure 2, the solubility limit of chloride (in terms of molality) is plotted as a function of the molality of nitrates. Note that this is not an isothermal plot; the temperature increases along the $\mathrm{x}$-axis. At lower nitrate concentration, chloride salt solubility decreases with increasing nitrate. However, for solutions with nitrate concentrations exceeding 50 molal, the amount of chloride able to dissolve became nearly constant and may have slightly increased in the most concentrated nitrate solutions. Unfortunately the experimental error at the highest concentrations also increased, and more testing would be required to determine if this trend was real or not. However, it was clear that the maximum chloride concentration was at least leveling off at the highest nitrate concentrations. Solution temperatures were above $140^{\circ} \mathrm{C}$ for these high nitrate compositions as can be seen in Figure 3.

The boiling points for the salt mixtures are functions of both nitrate and chloride concentrations and are plotted in Figure 3. The boiling point temperatures increased linearly with rising nitrate levels. At the higher nitrate concentrations, relatively small amounts of chloride can significantly elevate the solution boiling point; however, the extent of the boiling point elevation induced by chloride is limited by chloride solubility in these solutions.

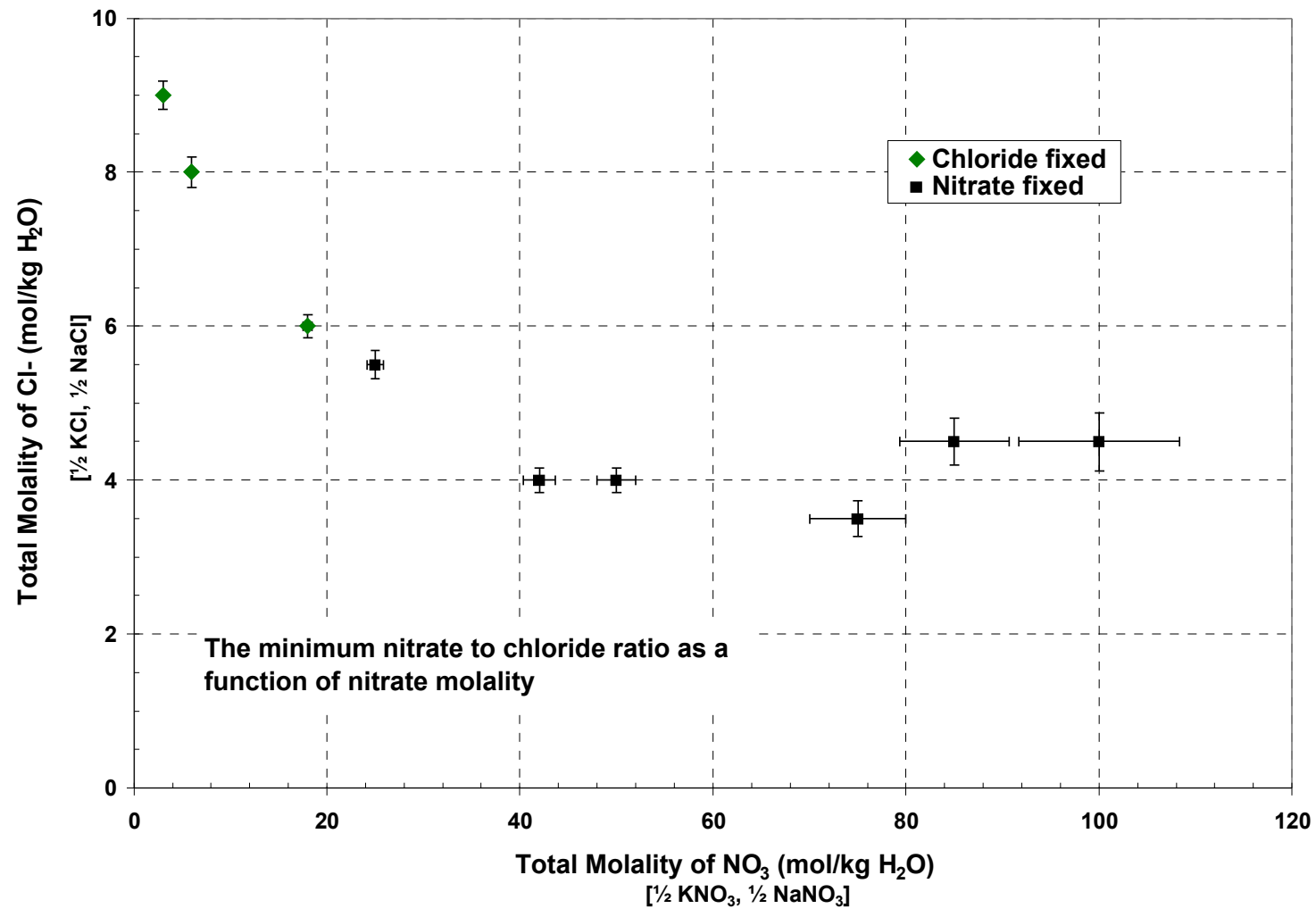

Figure 2. Maximum chloride concentration in nitrate aqueous solutions 


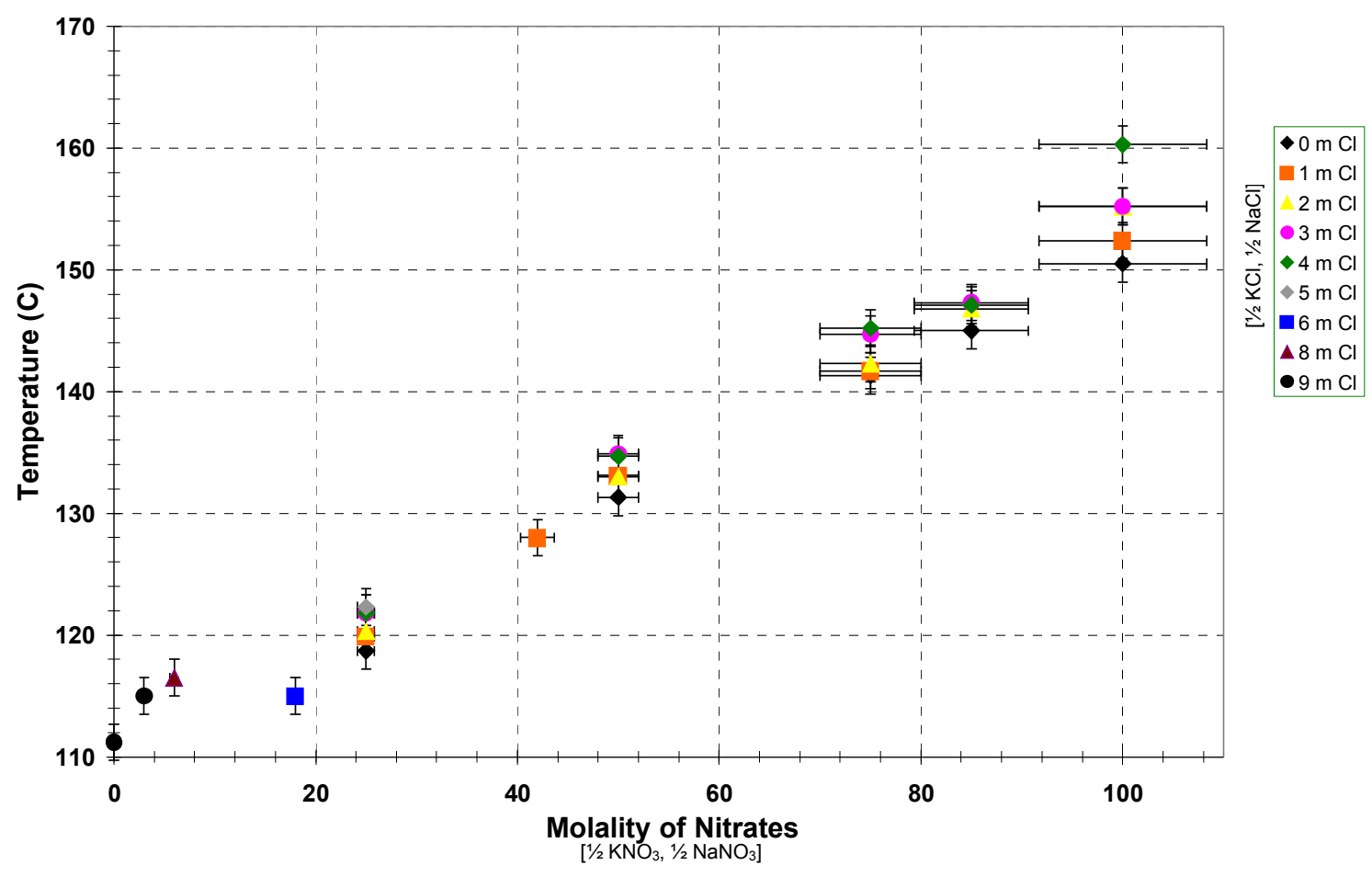

Figure 3. Boiling point temperatures for chloride-nitrate aqueous solutions. For nitrate concentrations greater than 20 molal, boiling points were measured to the chloride solubility limit for fixed nitrate solutions. For nitrate molalities less than 20 molal, boiling points were measured to the nitrate solubility limited for fixed chloride solutions except for the chloride only solution (i.e. $0 \mathrm{~m} \mathrm{NO}_{3}$ ). Only integer increments of chloride molality are plotted.

The relative humidity of the solutions at the maximum solubility was calculated from water vapor pressure [Weast and Astle 1981] at the boiling point temperatures of the solutions. Relative humidity is calculated as the ratio of the vapor pressure of the test solution (one atmosphere at boiling) divided by the vapor pressure of pure water at the same temperature.

This relative humidity is plotted as a function of chloride mole fraction (Figure 4). It is assumed that these points mark the phase diagram boundary that separates the liquid phase only region from the liquid + solid-chloride region. The points at zero mole fraction on the abscissa of the figure are for pure nitrate solutions.

Although the plot is a simplification (due to the inclusion of multiple temperature data) it is believed that this plot allows insight into whether or not these solutions provide a maximum chloride to nitrate ratio for a given relative humidity. The steepness of the phase boundary for $\mathrm{RH}$ less than 0.4 indicates that near minimum values of nitrate to 
chloride ratios are obtained using the experimental data in this region. However, above $0.4 \mathrm{RH}$, direct measurement of chloride solubility for a given nitrate concentration is needed in order to ensure testing at the minimum nitrate to chloride ratio. In terms of temperature, the concern about obtaining the maximum chloride in the solution composition applies primarily to the results obtained at temperatures less than about $120^{\circ} \mathrm{C}$.

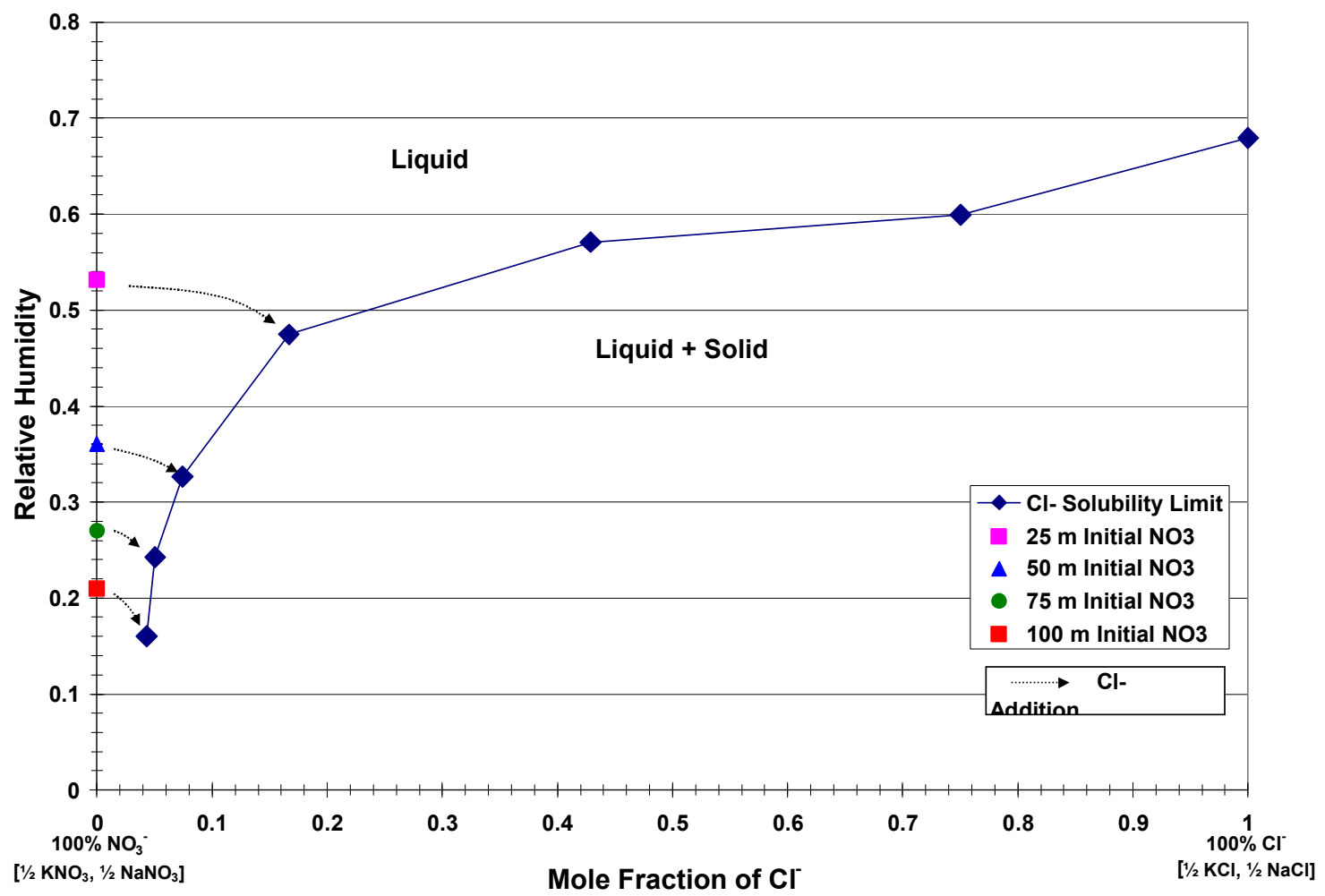

Figure 4. The phase boundary for chloride nitrate mixtures. This is not a typical phase diagram of similar appearance as this diagram includes data from several different temperatures.

Boiling points were obtained for equimolar $\mathrm{KNO}_{3}$ and $\mathrm{NaNO}_{3}$ solutions (see Figure 5). Included in the figure is the boiling point for the mutually saturated solution. All the points lie with a high level of precision along a linear trend. The highest boiling point measured here agrees well with that measured previously by Carroll et al.[2005a]. 


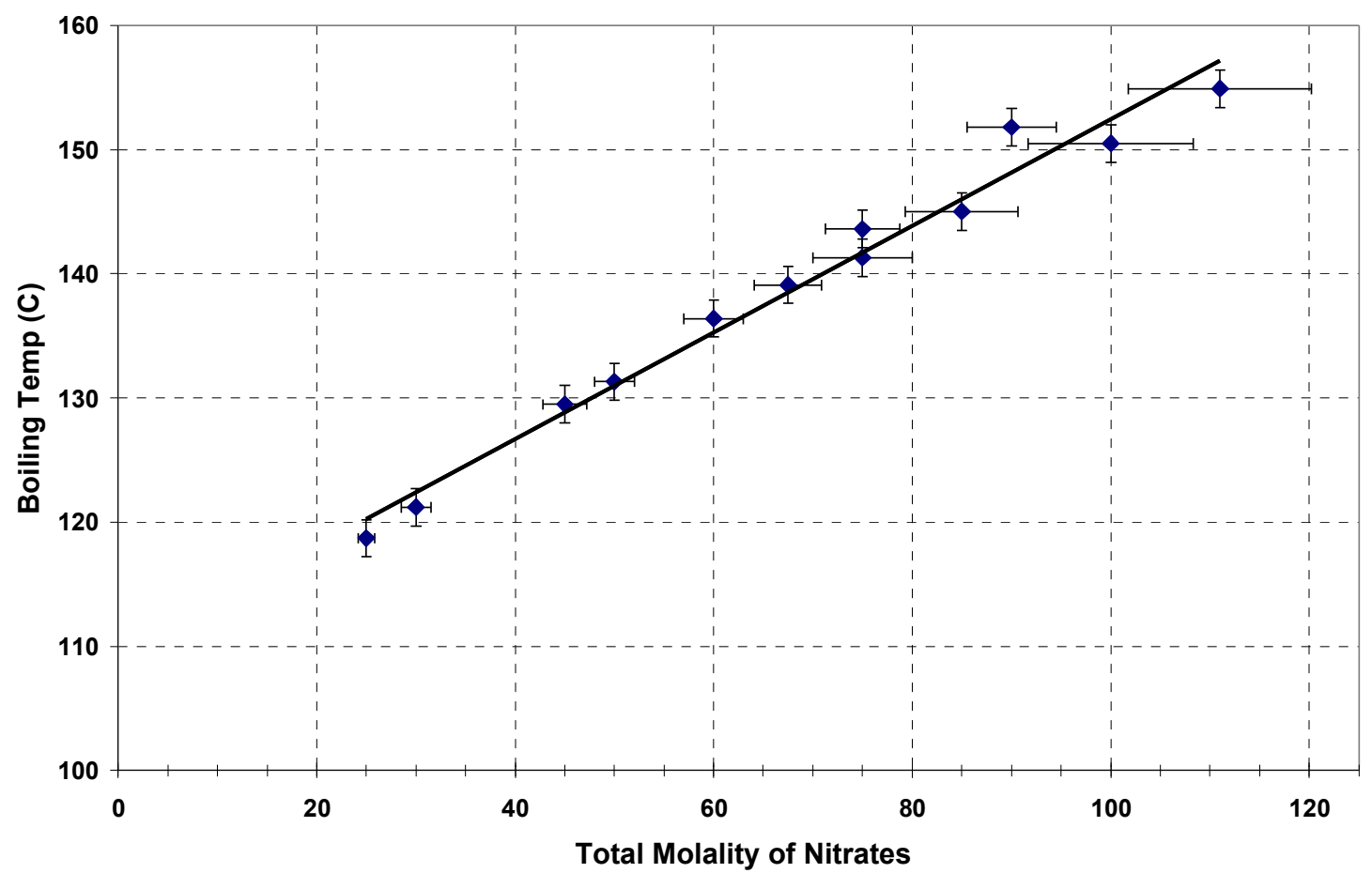

Figure 5. Measured boiling points for equimolar $\mathrm{KNO}_{3}$ and $\mathrm{NaNO}_{3}$ aqueous solutions. Note: That the calculated solution composition of $111 \mathrm{~m} \mathrm{NO}_{3}$ assumes that the starting solution contained $100 \mathrm{~m} \mathrm{NO}_{3}$ because it boiled at $150^{\circ} \mathrm{C}$, similar to another $100 \mathrm{~m} \mathrm{NO}_{3}$ solution in this study. However, entries in the scientific notebook for this solution indicate a slightly lower concentration because a $100 \mathrm{~g}$ addition of $\mathrm{NaNO}_{3}$ was not entered. It is assumed that the omission was inadvertent.

Nitrate to chloride ratios are important for corrosion applications because nitrate tends to reduce the aggressiveness of chloride as noted previously. Figure 6 shows the minimum $\mathrm{NO}_{3} / \mathrm{Cl}$ ratio for four-salt $\left(\mathrm{KNO}_{3}, \mathrm{NaNO}_{3}, \mathrm{KCl}, \mathrm{NaCl}\right)$ solutions as a function of boiling point temperature. These solutions contain the maximum amount of chloride for a given nitrate concentration at the boiling point. The results are important because they indicate that solutions with low $\mathrm{NO}_{3} / \mathrm{Cl}$ ratios are not possible at higher temperatures. Indeed ratios near 0.5 would require temperatures of $115^{\circ} \mathrm{C}$ or lower. Note: The four-salt $\mathrm{KNO}_{3}$ $\mathrm{NaNO}_{3}-\mathrm{KCl}-\mathrm{NaCl}$ system is factually the same as the "three-salt" $\mathrm{KNO}_{3}-\mathrm{NaNO}_{3}-\mathrm{NaCl}$ system, as $\mathrm{KCl}$ solid will spontaneously form from $\mathrm{KNO}_{3}$ and $\mathrm{NaCl}$ in this temperature range (cf. BSC 2004, Section 6.7.2.9). $\mathrm{KCl}$ also forms in the "two-salt" system $\mathrm{KNO}_{3}$ $\mathrm{NaCl}$ in this temperature range (without forming solid $\mathrm{NaNO}_{3}$ ). 


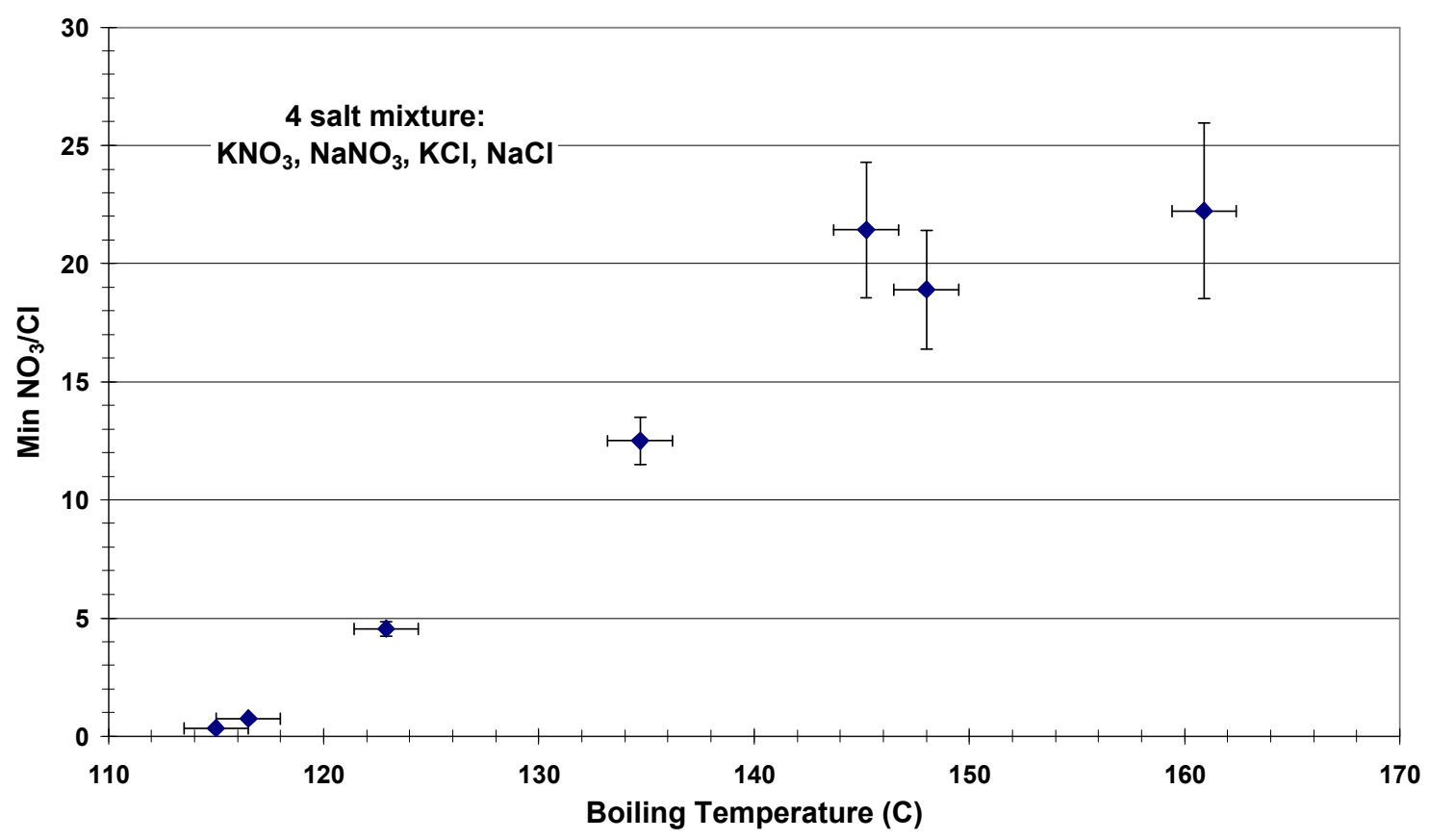

Figure 6. Minimum Nitrate to Chloride ratios for four-salt $\left(\mathrm{KNO}_{3}, \mathrm{NaNO}_{3}, \mathrm{KCl}\right.$, $\mathrm{NaCl})$ solutions with boiling temperatures above $115^{\circ} \mathrm{C}$

\section{$\underline{\text { Comparison with previous studies }}$}

Minimum $\mathrm{NO}_{3}$ to $\mathrm{Cl}$ ratios derived from solubility data from deliquescence testing agree well with the data in Figure 6. From data on a salt mixture of $\mathrm{NaCl}+\mathrm{NaNO}_{3}+\mathrm{KNO}_{3}$ at $120^{\circ} \mathrm{C}$ the measured solubility data give a minimum $\mathrm{NO}_{3}$ to $\mathrm{Cl}$ ratio that is about 5 [Carroll et al 2005b]. And from data on a salt mixture of $\mathrm{NaCl}+\mathrm{KNO}_{3}$ at $120^{\circ} \mathrm{C}$ the measured solubility data give a minimum $\mathrm{NO}_{3}$ to $\mathrm{Cl}$ ratio that is about 3 [Carroll et al 2005a]. From Figure 6, the interpolated minimum nitrate to chloride ratio is approximately 3 .

\section{2. $\quad E_{\text {corr }}$ evolution monitoring}

The dependence of $\mathrm{E}_{\text {corr }}$ on the aqueous solution acidity level is shown in Figure 7. The results are for a $25 \mathrm{~m} \mathrm{NO}_{3}+1 \mathrm{~m} \mathrm{Cl}$ aqueous solution at $110^{\circ} \mathrm{C}$. These results indicate a strong increase in $\mathrm{E}_{\text {corr }}$ when the $\log \left(\mathrm{H}^{+}\right.$molality) (subsequently referred to as " $\mathrm{pH}$ ") decreases from 3 to 2 . The steady state $\mathrm{E}_{\text {corr }}$ values at $\log \left(\mathrm{H}^{+}\right.$molality $)=2$ is very near the redox potentials for the following couples [Pourbaix 1974]: $\mathrm{NO}_{3}-\mathrm{NO}_{2}$ and $\mathrm{NO}_{3}-\mathrm{NH}_{4}$.

The $\mathrm{E}_{\text {corr }}$ values for the lower acidity solutions are far from these values, although there is a steady increase in $\mathrm{E}_{\text {corr }}$ values with increasing acidity. The increase in $\mathrm{E}_{\text {corr }}$ with 
increasing acidity is consistent with the known effect of nitrate becoming more oxidizing under more acidic conditions.

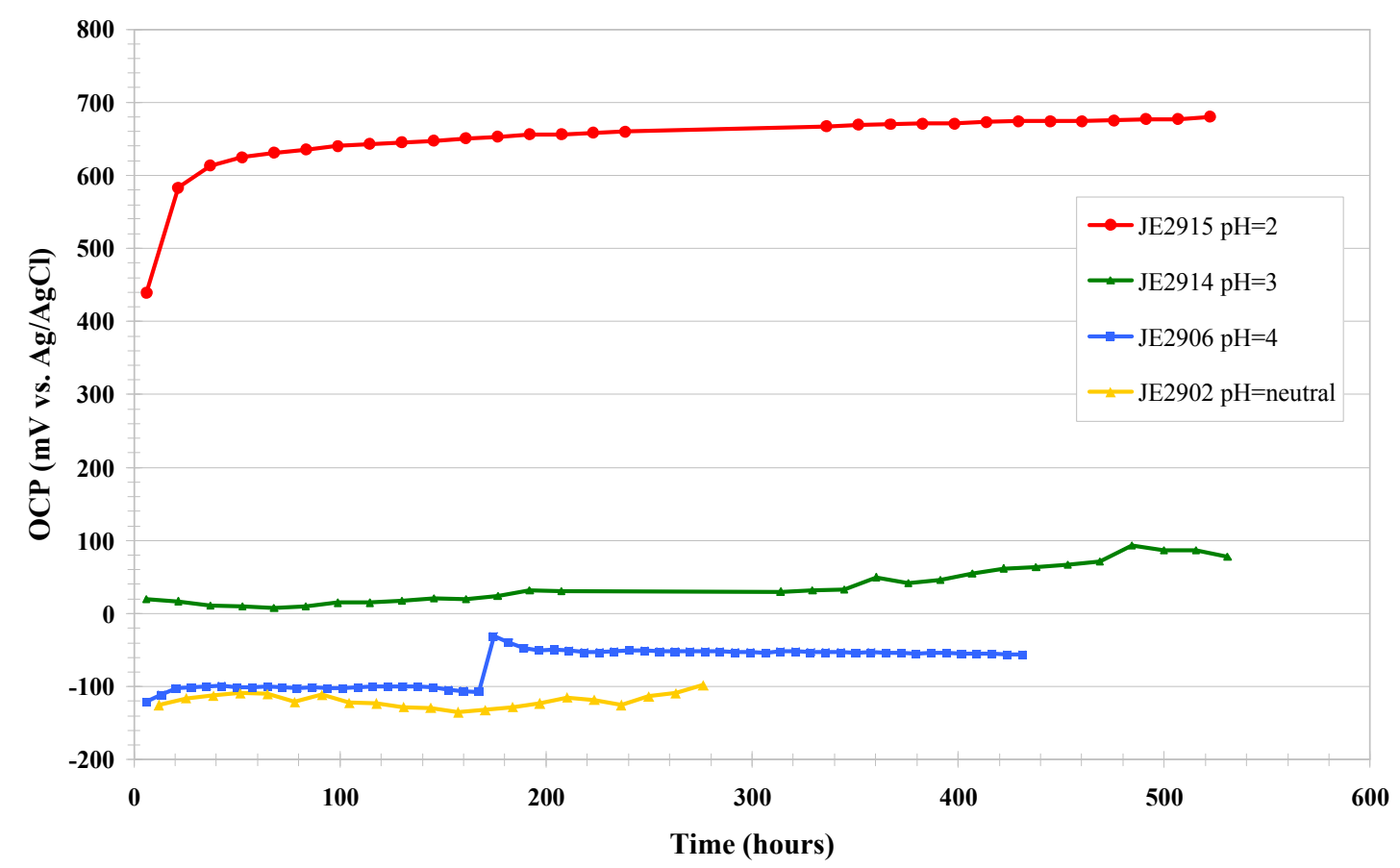

Figure 7. Effect of acidity on Alloy 22 prism open circuit potentials; [NO3] / [Cl] = 25:1, $110^{\circ} \mathrm{C}$ [DTN LL051001312251.155].

\section{3. $\quad E_{\text {crit }}$ determination with cyclic potentiodynamic polarization}

The results of the cyclic potentiodynamic polarization (CPP) testing are listed in Table 6 . The breakdown potential is reported as E20, and the repassivation potential as ER1. Also reported in the table is whether localized corrosion occurred or not. Optical microscopy was used to examine the surfaces to assess the occurrence of localized corrosion. Localized corrosion was not observed for temperatures greater than $125^{\circ} \mathrm{C}$. At $110^{\circ} \mathrm{C}$, localized corrosion was observed at nitrate to chloride ratios up to 1 , the highest ratio tested. The extent of localized corrosion was confined to the crevice region, and was limited for ratios greater than or equal to 0.3 . 
Table 6. Summary of $E_{\text {crit }}$ determination studies including solution composition \& temperature, and occurrence of localized corrosion as determined by optical microscopy. DTN: LL051001012251.154.

\begin{tabular}{|c|c|c|c|c|c|c|c|c|c|c|}
\hline $\begin{array}{c}\text { Sample } \\
\text { ID }\end{array}$ & $\begin{array}{l}\text { Temp } \\
\left({ }^{\circ} \mathrm{C}\right)\end{array}$ & $\begin{array}{c}\log \left(\mathrm{H}^{+}\right. \\
\text {molality) }\end{array}$ & $\begin{array}{c}\mathrm{Cl} \\
\text { (molal) }\end{array}$ & $\begin{array}{c}\mathrm{NO}_{3} \\
\text { (molal) }\end{array}$ & $\mathrm{NO}_{3} / \mathrm{Cl}$ & \begin{tabular}{|c|} 
Localized \\
Corrosion \\
(Yes/No)
\end{tabular} & $\begin{array}{c}\text { Ecorr } \\
(24 \mathrm{hr}) \\
(\mathrm{V}, \\
\text { Ag/AgCl) }\end{array}$ & $\begin{array}{c}\text { E20 } \\
\text { (V, } \\
\text { Ag/AgCl) }\end{array}$ & $\begin{array}{c}\text { ER1 } \\
\text { (V, } \\
\text { Ag/AgCl) }\end{array}$ & Notes \\
\hline \multicolumn{11}{|c|}{ Cyclic Polarization Tests: } \\
\hline KE0592 & 90 & neutral & 8 & 0.8 & 0.1 & Yes & -0.12 & 0.727 & 0.570 & \\
\hline KE0688B & 90 & neutral & 8 & 0.8 & 0.1 & Yes & -0.501 & 0.683 & -0.063 & Re-use specimen \\
\hline KE0590 & 90 & neutral & 8 & 1.6 & 0.2 & Yes & -0.485 & 0.694 & 0.401 & \\
\hline KE0693B & 90 & neutral & 8 & 1.6 & 0.2 & Yes & -0.491 & 0.687 & 0.382 & Re-use specimen \\
\hline & & & & & & & & & & \\
\hline KE0588 & 110 & $\begin{array}{c}\text { Not } \\
\text { determined }\end{array}$ & 8 & 0 & 0 & Yes & -0.321 & 0.035 & -0.180 & $4 \mathrm{~m} \mathrm{CaCl} \mathrm{C}_{2}$ \\
\hline KE0689 & 110 & neutral & 8 & 0 & 0 & Yes & -0.557 & 0.085 & -0.200 & \\
\hline KE0691 & 110 & neutral & 8 & 0 & 0 & Yes & -0.555 & 0.048 & -0.182 & \\
\hline KE0687 & 110 & neutral & 8 & 0.8 & 0.1 & Yes & -0.521 & 0.360 & -0.047 & \\
\hline KE0692 & 110 & neutral & 8 & 0.8 & 0.1 & Yes & -0.397 & 0.552 & -0.096 & \\
\hline KE0589 & 110 & neutral & 8 & 1.6 & 0.2 & Yes & -0.528 & 0.466 & -0.017 & \\
\hline KE0591 & 110 & neutral & 8 & 2.4 & 0.3 & Yes & -0.558 & 0.587 & 0.320 & $\begin{array}{l}\text { Slight localized } \\
\text { corrosion under } \\
\text { the crevice. }\end{array}$ \\
\hline KE0580 & 110 & neutral & 8 & 4 & 0.5 & Yes & -0.521 & 0.620 & 0.328 & $\begin{array}{l}\text { Slight localized } \\
\text { corrosion under } \\
\text { the crevice. }\end{array}$ \\
\hline KE0690 & 110 & neutral & 6 & 6 & 1 & Yes & -0.543 & 0.600 & 0.383 & $\begin{array}{l}\text { Slight localized } \\
\text { corrosion under } \\
\text { the crevice. }\end{array}$ \\
\hline KE0581 & 110 & neutral & 6 & 6 & 1 & Yes & 0.216 & 0.684 & 0.522 & \begin{tabular}{|l|} 
Slight localized \\
corrosion under \\
the crevice.
\end{tabular} \\
\hline KE0574 & 110 & 4 & 8 & 0 & 0 & Yes & -0.412 & 0.049 & -0.207 & \\
\hline KE0573 & 110 & 4 & 8 & 0.8 & 0.1 & Yes & -0.376 & 0.508 & -0.097 & \\
\hline KE0572 & 110 & 4 & 8 & 4 & 0.5 & Yes & -0.303 & 0.668 & 0.443 & $\begin{array}{l}\text { Slight localized } \\
\text { corrosion under } \\
\text { the crevice. }\end{array}$ \\
\hline KE0571 & 110 & 4 & 6 & 6 & 1 & Yes & 0.195 & 0.650 & 0.444 & $\begin{array}{l}\text { Slight localized } \\
\text { corrosion under } \\
\text { the crevice. }\end{array}$ \\
\hline KE0575 & 110 & 4 & 6 & 6 & 1 & Yes & -0.406 & 0.684 & 0.480 & $\begin{array}{l}\text { Slight localized } \\
\text { corrosion under } \\
\text { the crevice. } \\
\end{array}$ \\
\hline KE0695 & 110 & neutral & 2 & 42 & 21 & No & -0.232 & 0.828 & 0.674 & \\
\hline KE0696 & 110 & neutral & 1 & 42 & 42 & No & -0.427 & 0.846 & 0.690 & \\
\hline KE0280 & 110 & neutral & 0 & 42 & $\mathrm{~N} / \mathrm{A}$ & No & -0.360 & 0.855 & 0.773 & \\
\hline KE0582 & 110 & 4 & 4 & 42 & 10.5 & No & -0.108 & 0.779 & 0.654 & \\
\hline KE0583 & 110 & 4 & 2 & 42 & 21 & No & -0.297 & 0.816 & 0.661 & \\
\hline KE0584 & 110 & 4 & 1 & 42 & 42 & No & -0.323 & 0.829 & 0.661 & \\
\hline & & & & & & & & & & \\
\hline KE0697 & 125 & neutral & 4 & 42 & 10.5 & No & -0.438 & 0.777 & 0.622 & \\
\hline KE0698 & 125 & neutral & 4 & 42 & 10.5 & No & -0.471 & 0.780 & 0.683 & \\
\hline KE0586 & 125 & neutral & 2 & 42 & 21 & No & -0.202 & 0.749 & 0.595 & \\
\hline KE0686 & 125 & neutral & 1 & 42 & 42 & No & -0.528 & 0.749 & 0.608 & \\
\hline
\end{tabular}




\begin{tabular}{|c|c|c|c|c|c|c|c|c|c|c|}
\hline KE0281 & 125 & neutral & 0 & 42 & N/A & No & -0.412 & 0.781 & 0.685 & \\
\hline KE0585 & 125 & 4 & 4 & 42 & 10.5 & No & -0.234 & 0.743 & 0.540 & \\
\hline KE0587 & 125 & 4 & 2 & 42 & 21 & No & -0.406 & 0.765 & 0.590 & \\
\hline KE0576 & 125 & 4 & 1 & 42 & 42 & No & -0.242 & 0.785 & 0.685 & \\
\hline KE0578 & 140 & 4 & 1 & 72 & 72 & No & -0.351 & 0.790 & 0.640 & \\
\hline KE0577 & 140 & neutral & 1 & 72 & 72 & No & -0.383 & 0.820 & 0.725 & \\
\hline KE0699 & 140 & neutral & 3 & 76 & 25.3 & No & -0.13 & 0.783 & 0.623 & \\
\hline KE0700 & 140 & neutral & 3 & 76 & 25.3 & No & -0.418 & 0.785 & 0.656 & \\
\hline KE0595 & 150 & neutral & 1 & 100 & 100 & No & -0.334 & 0.785 & 0.671 & \\
\hline \multicolumn{11}{|c|}{ Potentiostatic Tests: } \\
\hline KE0593 & 110 & neutral & 8 & 0.8 & 0.1 & Yes & \multicolumn{4}{|c|}{$\begin{array}{l}\text { Eapp }=0.05 \text { V. Severe attack with no stifling } \\
\text { observed }\end{array}$} \\
\hline KE0594 & 110 & neutral & 8 & 1.6 & 0.2 & Yes & \multicolumn{4}{|c|}{$\begin{array}{l}\text { Eapp }=0.05 \text { V. Severe attack with no stifling } \\
\text { observed }\end{array}$} \\
\hline & & & & & & & & & & \\
\hline
\end{tabular}

Figures 8 and 9 are plots of the E20 and ER1 dependence on $\mathrm{NO}_{3} / \mathrm{Cl}$ ratio. These plots graphically illustrate that there is no discernable difference in E20 and ER1 values for $\mathrm{NO}_{3}$ to $\mathrm{Cl}$ ratios greater than about 10 . No localized corrosion was observed for these values. For ratios between 0 and 10 there is a steady increase in both ER1 and E20. Localized corrosion observed up to a ratio of 1 .

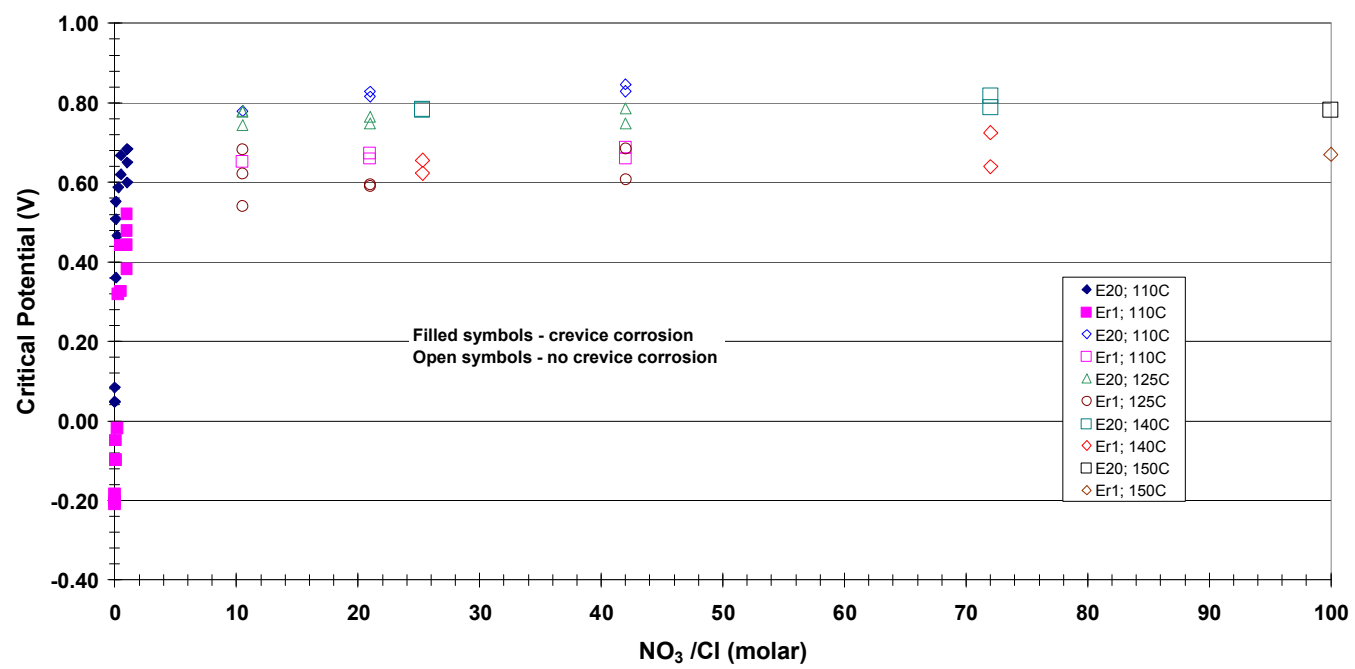

Figure 8. $\mathrm{E} 20$ and $\mathrm{ER} 1$ as a function of $\mathrm{NO}_{3}$ to $\mathrm{Cl}$ ratio. 


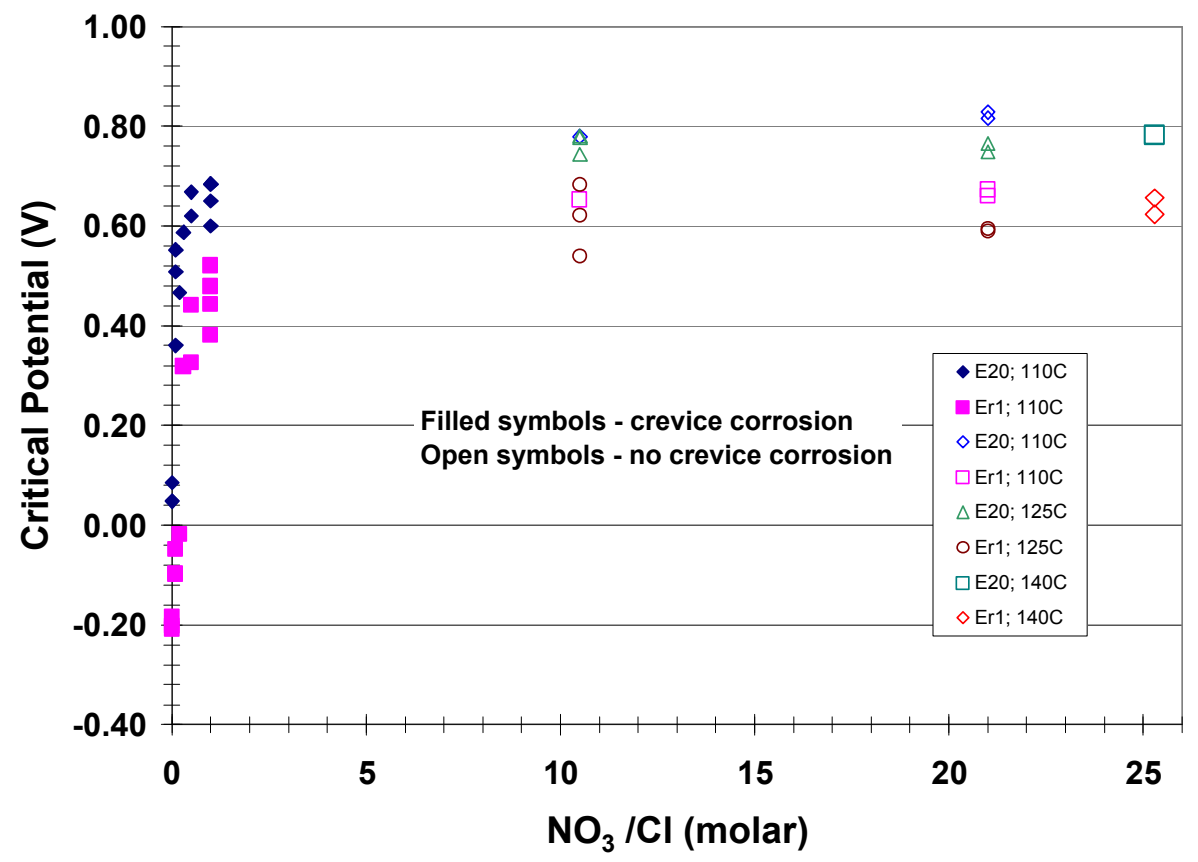

Figure 9. E20 and ER1 as a function of $\mathrm{NO}_{3}$ to $\mathrm{Cl}$ ratio.

Figures 10 and 11 are illustrative examples of the electrochemical results for which no localized corrosion occurred and for which localized corrosion occurred.

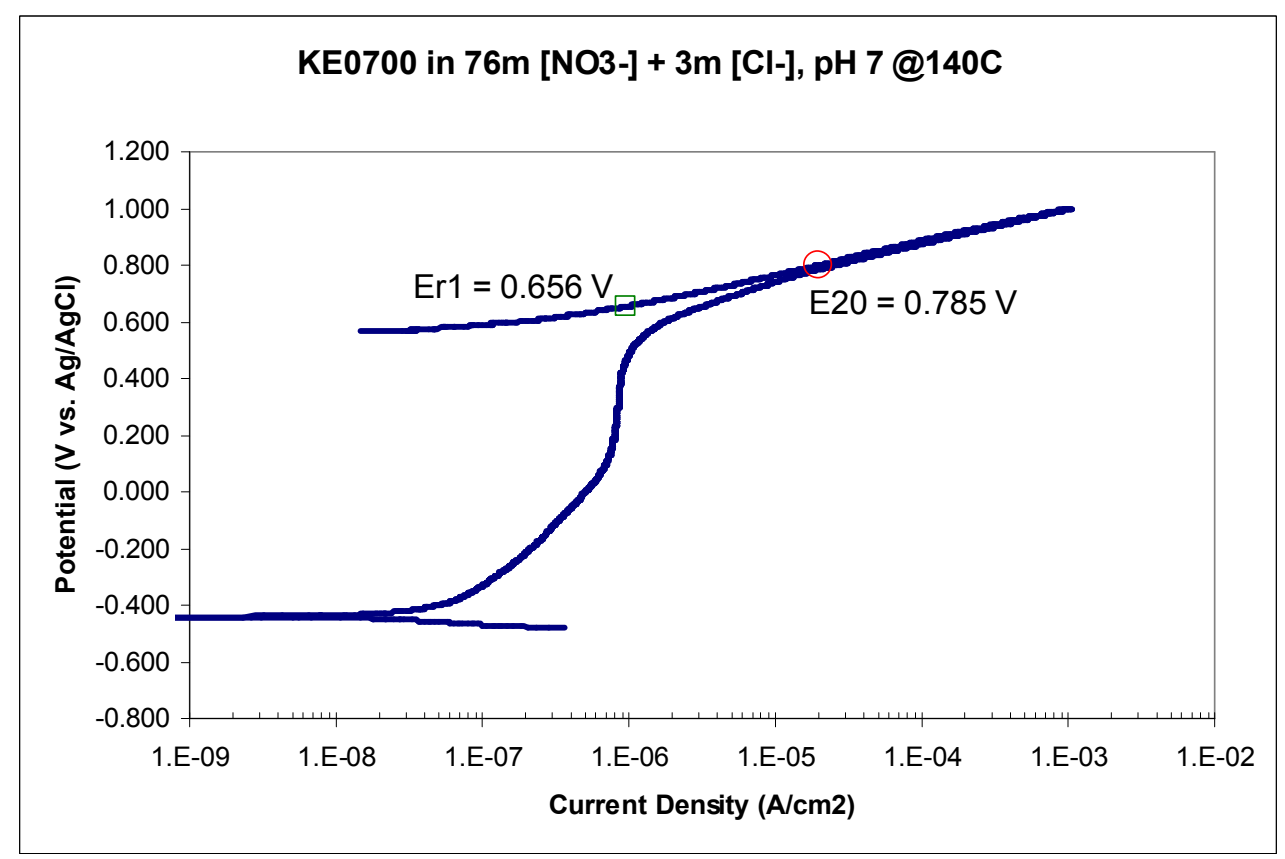

Figure 10. CPP curve showing no localized corrosion. DTN: LL050906112251.152 


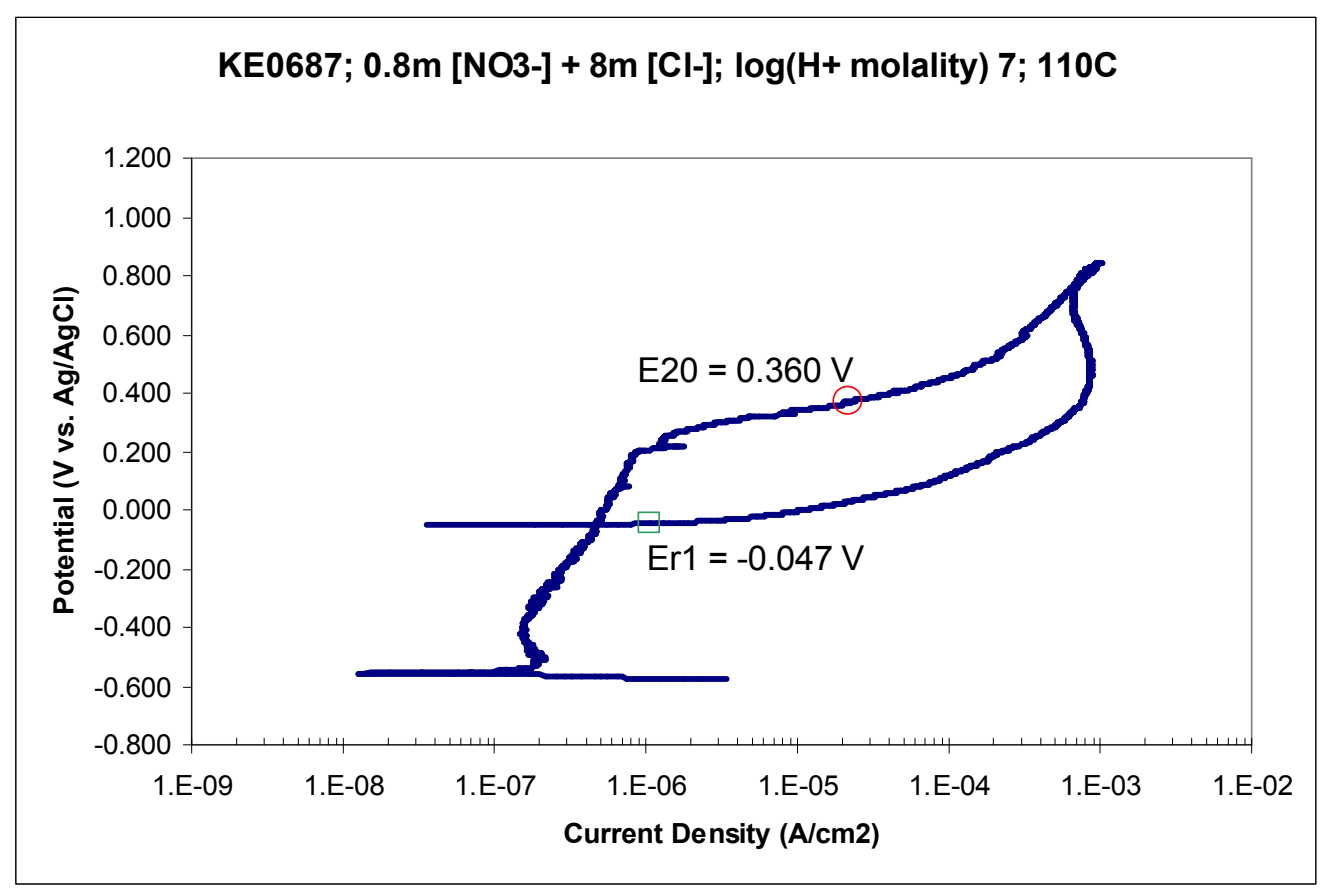

Figure 11. CPP curve showing localized corrosion. DTN: LL050906112251.152

Figures 12-17 are optical images of the specimens tested at $110^{\circ} \mathrm{C}$ illustrating the decreasing extent of localized corrosion with increasing $\mathrm{NO}_{3} / \mathrm{Cl}$ ratios. As illustrated the localized corrosion that did occur was confined to the region underneath the crevice former. 
Figure 12. After CPP test in $8 \mathrm{~m}\left[\mathrm{Cl}^{-}\right]+4 \mathrm{~m}\left[\mathrm{NO}_{3}{ }^{-}\right]$solution, $\left[\mathrm{NO}_{3}{ }^{-}\right] /\left[\mathrm{Cl}^{-}\right]$of $0.5: 1$, and $110^{\circ} \mathrm{C}$. Limited crevice corrosion was observed optically. Specimen ID \# KE0580.

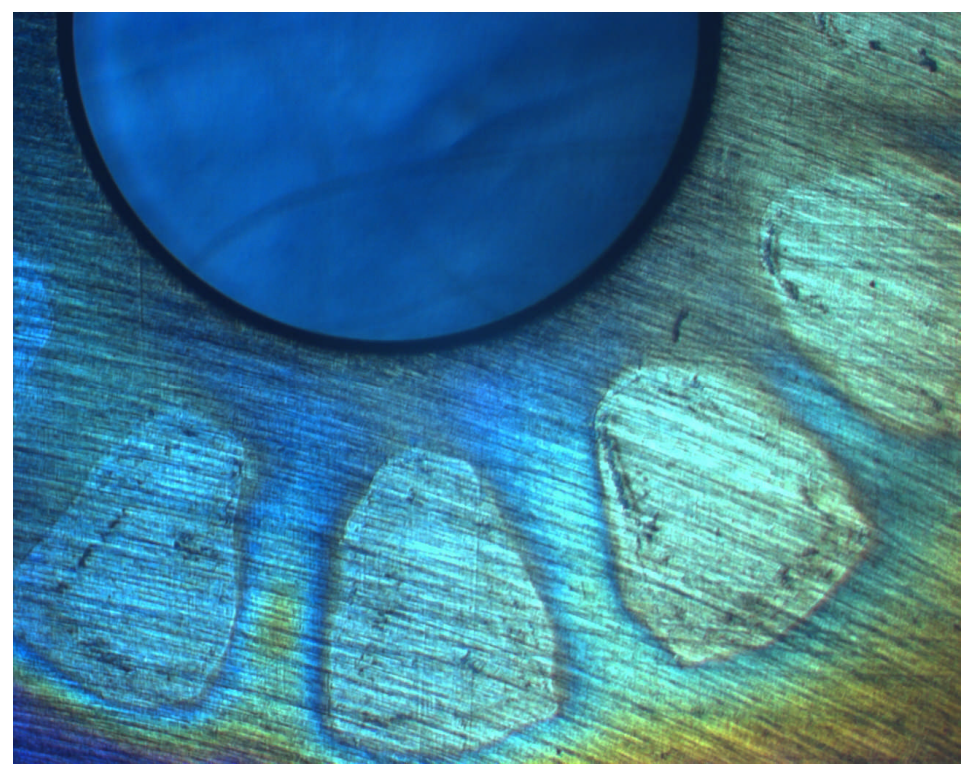


Figure 13. After CPP test in $6 \mathrm{~m}\left[\mathrm{Cl}^{-}\right]+6 \mathrm{~m}\left[\mathrm{NO}_{3}{ }^{-}\right]$solution, $\left[\mathrm{NO}_{3}{ }^{-}\right] /\left[\mathrm{Cl}^{-}\right]$of $1: 1$, and $110^{\circ} \mathrm{C}$. Limited crevice corrosion was observed optically. Specimen ID \# KE0581.
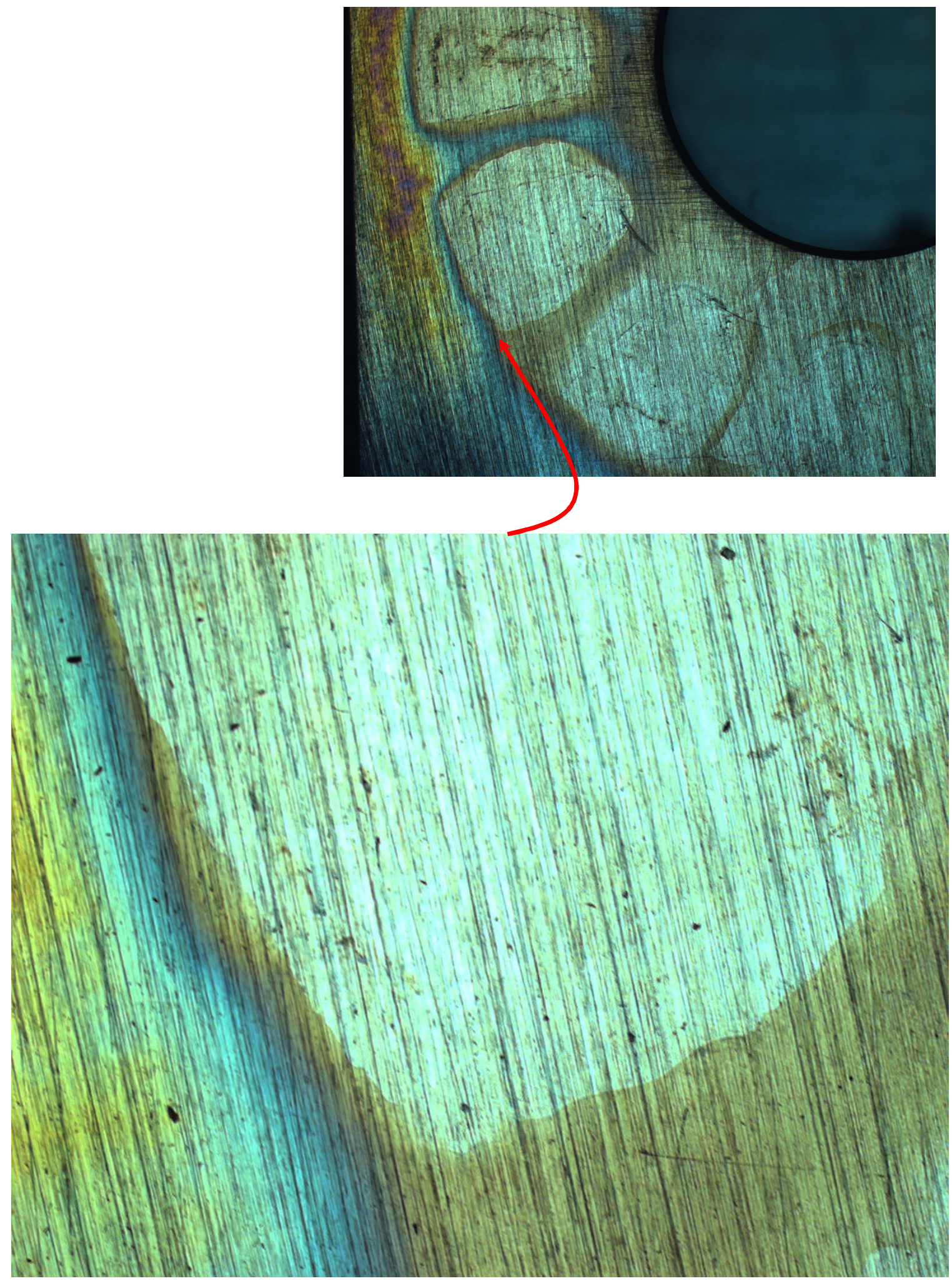
Figure 14. After CPP test in $8 \mathrm{~m}\left[\mathrm{Cl}^{-}\right]+0.8 \mathrm{~m}\left[\mathrm{NO}_{3}{ }^{-}\right]$solution, $\left[\mathrm{NO}_{3}{ }^{-}\right] /\left[\mathrm{Cl}^{-}\right]$of $0.1: 1$, and $110^{\circ} \mathrm{C}$. Crevice corrosion was observed optically. Specimen ID \# KE0587.

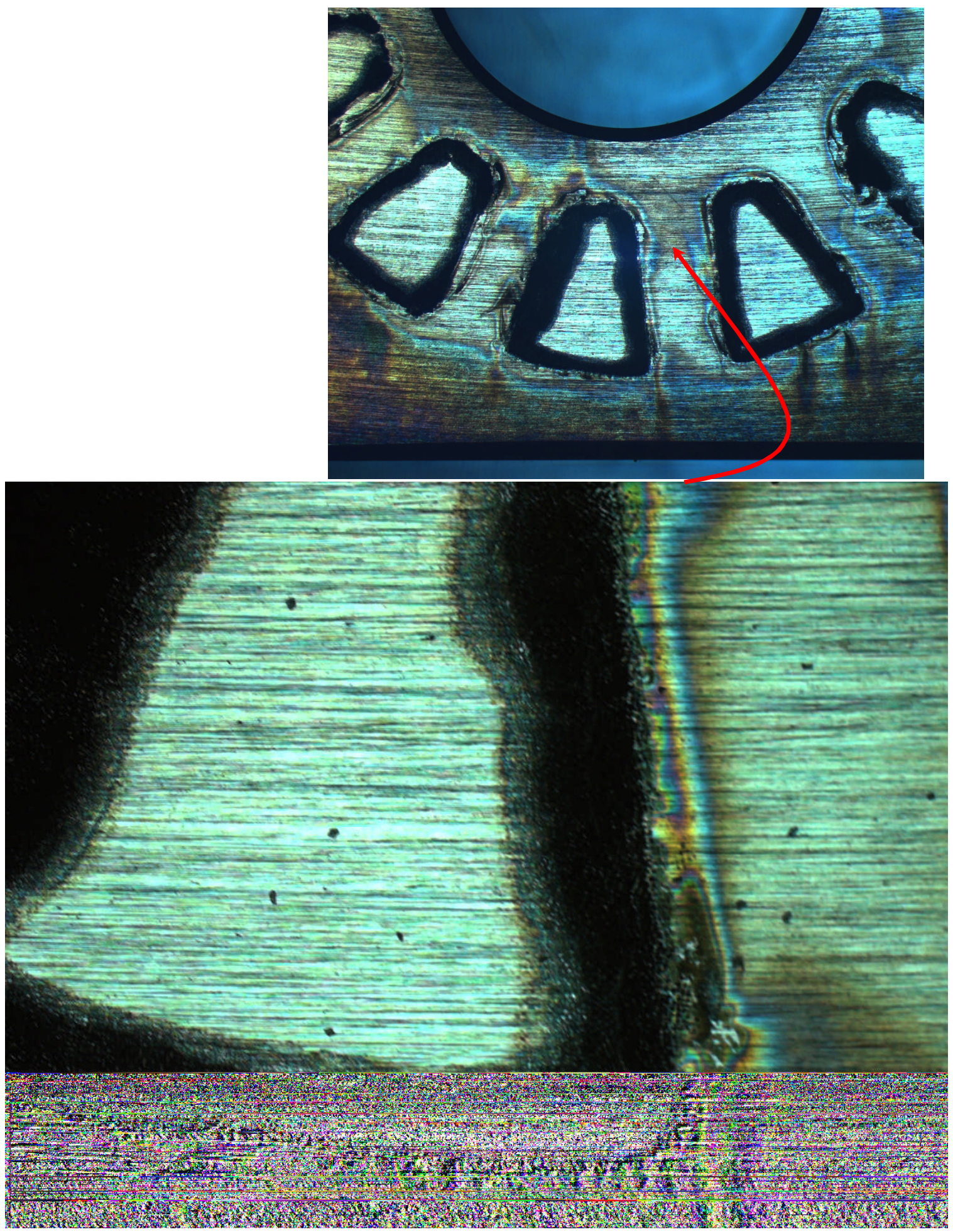




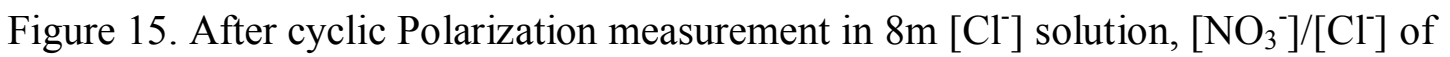
$0: 1$, and $110^{\circ} \mathrm{C}$. Crevice corrosion was observed optically. Specimen ID \# KE0689

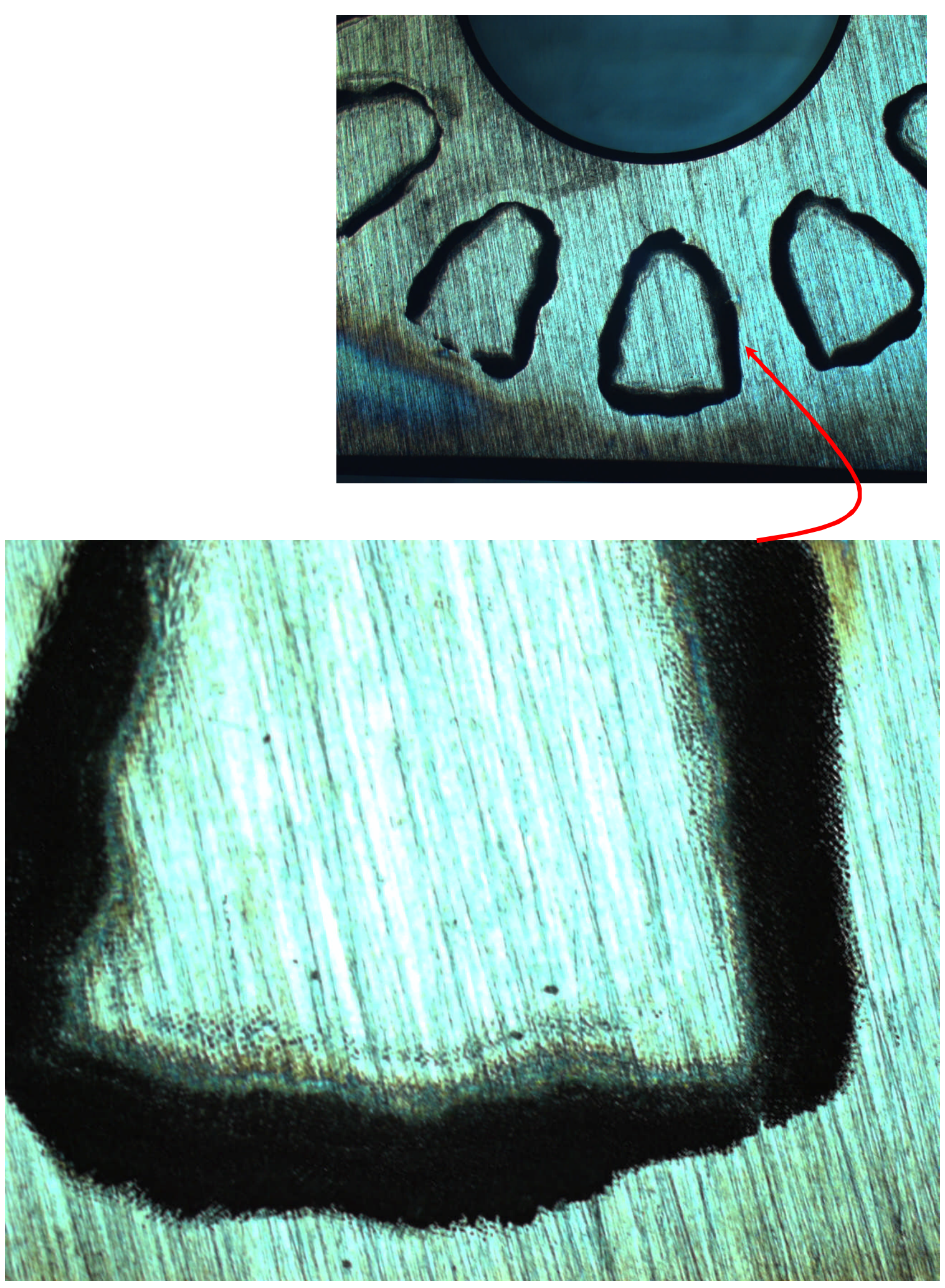


Figure 16. After CPP test in $1 \mathrm{~m}\left[\mathrm{Cl}^{-}\right]+72 \mathrm{~m}\left[\mathrm{NO}_{3}{ }^{-}\right]$solution, $\left[\mathrm{NO}_{3}{ }^{-}\right] /\left[\mathrm{Cl}^{-}\right]$of $72: 1$, and $140^{\circ} \mathrm{C}$. No crevice corrosion was observed optically. Specimen ID\#KE0578
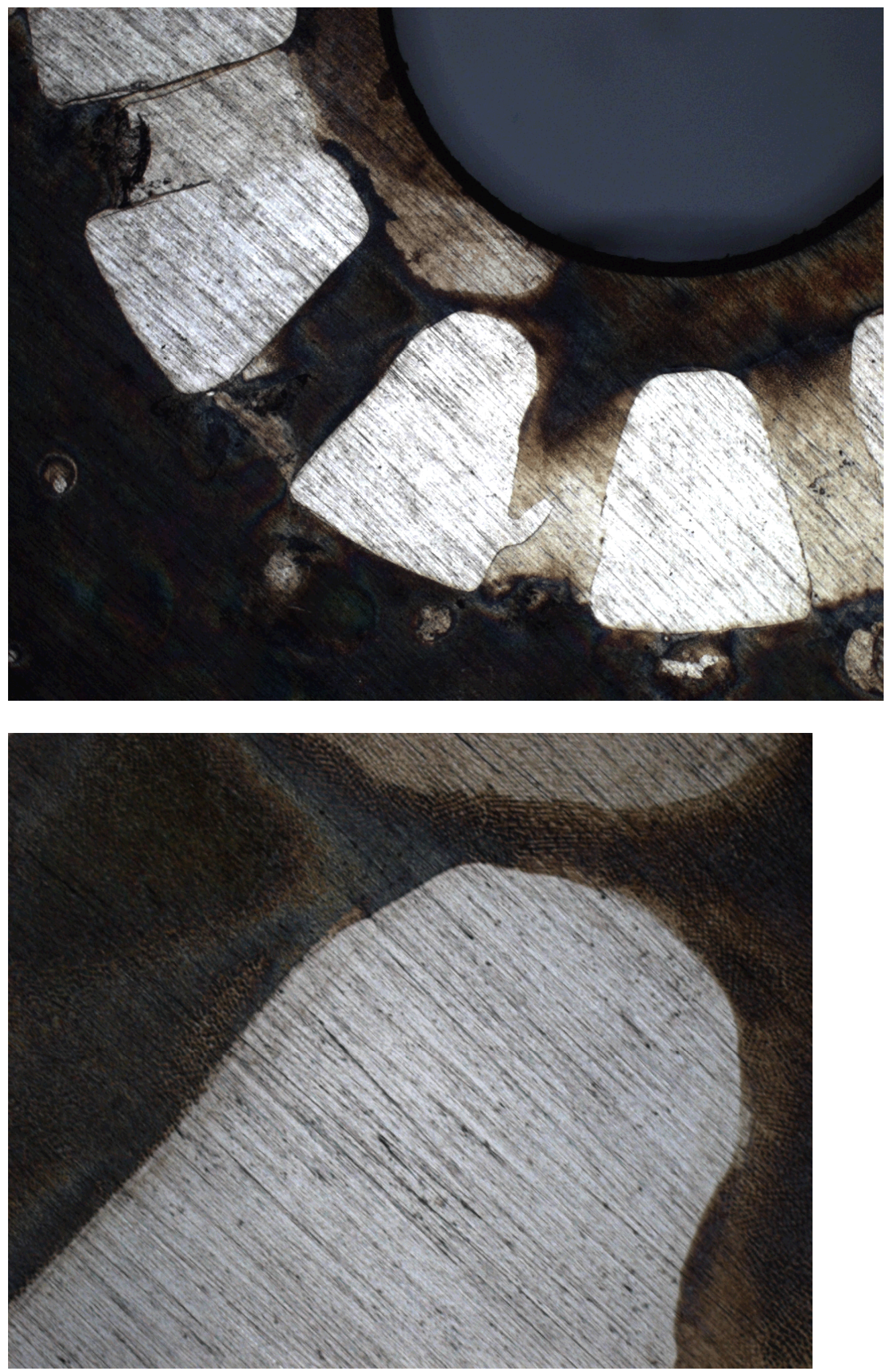


\section{$\underline{\text { Comparison with previous studies }}$}

In order to compare the effect of the solution cation on localized corrosion susceptibility of Alloy 22, a CPP test was run in an $8 \mathrm{~m} \mathrm{Cl}^{-}$solution formulated with $\mathrm{CaCl}_{2}$ and at $110^{\circ} \mathrm{C}$. The CPP curve is shown in Figure 17. The CPP curves for $8 \mathrm{~m} \mathrm{Cl}^{-}$solution formulated with $\mathrm{NaCl}+\mathrm{KCl}$ are shown for comparison. The data indicates similar electrochemical $\mathrm{E}_{\text {crit }}$ values. Similar morphology of attack - limited to crevice region was also seen. However, the $24 \mathrm{hr} \mathrm{E}_{\text {corr }}$ value was higher for the calcium based solution; this is probably due to the more acidic calcium based solution.

The morphology of attack for this calcium based test is different than those that have been noted previously. In the previous studies massive attack occurred outside of the crevice region. This could be do to the much higher chloride contents used in those studies and the higher "turn around current" used for reversing the CPP scan.

The data presented in this report are also consistent with previously obtained data for sodium based chloride and nitrate solutions. Those tests likewise showed that nitrate inhibition of localized corrosion of Alloy 22 in the temperature range 60 to $100^{\circ} \mathrm{C}$ increases with increasing nitrate to chloride ratio. No localized corrosion was observed for the ratio of 0.5 at $100^{\circ} \mathrm{C}$ and at 0.15 at $60^{\circ} \mathrm{C}$. These results combined with the present study suggest that in addition to nitrate to chloride ratio that temperature and absolute chloride and nitrate levels may affect localized corrosion susceptibility. 


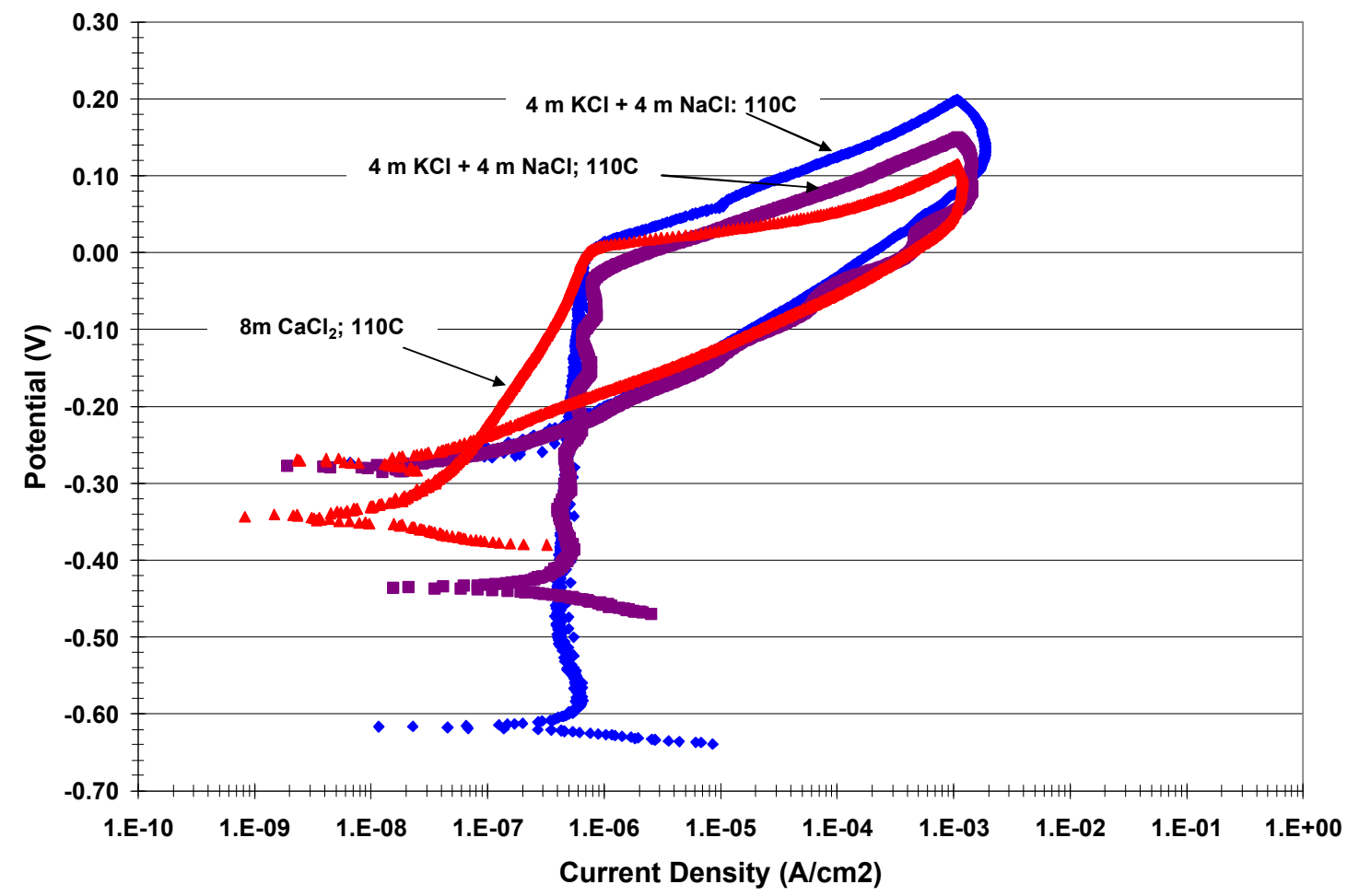

Figure 17. CPP curves for $8 \mathrm{~m} \mathrm{Cl}$ test solutions. LL050906112251.152 


\section{References}

\section{DOCUMENTS CITED}

BSC (Bechtel SAIC Company) 2004. Environment on the Surfaces of the Drip Shield and Waste Package Outer Barrier. ANL-EBS-MD-000001 REV 01. Las Vegas, Nevada: Bechtel SAIC Company. ACC: DOC.20041116.0005. DIRS: 161237.

Brossia, C.S. and Kelly, R.G. 1998. "Influence of alloy sulfur content and bulk electrolyte composition on crevice corrosion initiation of austenitic stainless steel," Corrosion 54(2), 145-154.

Carroll, S., Alai, M., Craig, L., Gdowski, G., Hailey, P., Nguyen, G., Rard, J., Staggs, K., Sutton, M., Wolery, T. (2005a). Chemical Environment at Waste Package Surfaces in a High-Level Radioactive Waste Repository. UCRL-TR-212566, Lawrence Livermore National Laboratory, Livermore, California.

Carroll, S., Rard, J., Staggs, K., Wolery, T. Alai, M., (2005b). Brines Formed by MultiSalt Deliquescence. UCRL-TR-217062 Lawrence Livermore National Laboratory, Livermore, California.

Ilevbare, G.O., King, K.J., Gordon, S.R., Elayat, H.A., Gdowski, G.E., and Gdowski, T.S.E. 2005. "Effect of Nitrate on the Repassivation Potential of Alloy 22 in ChlorideContaining Environments," Journal of The Electrochemical Society, 152 (12) B547B554.

Kracek, F.C. 1928. "P-T-X Relations for Systems of Two or More Components and Containing Two or More Phases (L-V, LI-LII-V and S-L-V) Systems).” P. 368. International Critical Tables of Numerical Data, Physics, Chemistry and Technology. Washburn, E.W., ed. Volume III. $1^{\text {st }}$ Edition. New York, New York: McGraw-Hill. TIC: 243268. DIRS: 122125.

Linke, W.F. 1965. "Solubilities: Inorganic and Metal-Organic Compounds." Volume II, $K-Z$. 4th Edition. Page 250. Washington, D.C.: American Chemical Society. TIC: 254489. DIRS: 163041.

Pourbaix, M. 1974. Atlas of Electrochemical Equilibria in Aqueous Solutions. Houston, Texas: National Association of Corrosion Engineers. TIC: 208955. DIRS: 100817.

Rard, J. 2004. Results from Boiling Temperature Measurements for Saturated Solutions in the Systems $\mathrm{NaCl}+\mathrm{KNO}_{3}+\mathrm{H}_{2} \mathrm{O}, \mathrm{NaNO}_{3}+\mathrm{KNO}_{3}+\mathrm{H}_{2} \mathrm{O}$, and $\mathrm{NaCl}+\mathrm{NaNO}_{3}+$ $\mathrm{KNO}_{3}+\mathrm{H}_{2} \mathrm{O}$. UCRL-TR-207054, Lawrence Livermore National Laboratory, Livermore, California. 
Weast, R.C. and Astle, M.J., eds. 1981. CRC Handbook of Chemistry and Physics. 62nd Edition. Boca Raton, Florida: CRC Press. TIC: 240722. DIRS: 100833.

\section{SOURCE DATA, LISTED BY DATA TRACKING NUMBER}

LL050904812251.151. Effect of pH on Corrosion Potential of Alloy 22 Prism Samples; Nitrate to Chloride Ratio of 25:1 110 Degrees C. Submittal date: 10/26/2005.

LL050906112251.152. Electrochemical Polarization Measurements of Alloy 22 in High Concentrated Brines at Temperatures from 90 to 150 Degrees Celsius. Submittal date: $10 / 11 / 2005$.

LL051001012251.154. Localized Corrosion Susceptibility of Alloy 22 in High Concentrated Brines at Temperatures from 90 to 150 Degrees Celsius. Submittal date: $10 / 11 / 2005$.

LL051001312251.155. Excel Table and Plot Displaying the Effect of $\mathrm{pH}$ on Corrosion Potential of Alloy 22 Prism Samples; Nitrate to Chloride Ratio of 25:1, 110 Degrees C. Submittal date: 10/31/2005.

LL051100623121.054 Na-K-NO $-\mathrm{Cl}$ Aqueous Solution Compositions at 110 to $160 \mathrm{C}$; Support to Electrochemical Studies. 
Appendix A. Calculation of uncertainties for the aqueous solution chemistry studies.

This appendix describes the methodology used to calculate the uncertainty associated with the aqueous solution chemistry measurements. Uncertainties took into consideration both the smallest scale of the instrument along with an estimate of the testing apparatus' capacity to control the parameter.

Temperature - The resolution of the digital thermometers was $0.1^{\circ} \mathrm{C}$, however the thermometers were only calibrated with a tolerance of $1.0^{\circ} \mathrm{C}$. The readings were not always steady when boiling was observed so the uncertainty estimate was $1.5^{\circ} \mathrm{C}$.

Mass $\mathrm{H}_{2} \mathrm{O}$ - The relatively large water mass uncertainty $\left(\Delta\right.$ mass $\left._{\mathrm{H} 2 \mathrm{O}}\right)$ is estimated as $10.0 \mathrm{~g}$ and is the result of considerations of experimental setup. Water losses could occur through the seals on the vessels and through the condenser. In addition water losses could occur during the high temperature addition of the salt through an open port. The latter loss was somewhat reduced by lowering the temperature of the test solution during the salt additions in order to reduce the water vapor pressure.

Salt Mass- The estimated salt mass uncertainty (e,g, $\left.\Delta \operatorname{mass}_{\mathrm{Cl}}\right)$ is also due to considerations of the experimental set-up. The analytical balance was calibrated with a tolerance of $0.1 \mathrm{~g}$. Uncertainty was estimated to be $0.3 \mathrm{~g}$ because some non-dissolved salt would stick to the side of the vessel, and in addition, small amounts of salt precipitates formed near the nitrogen bubbler inlet. The latter effect was probably due to the solution cooling by the inlet nitrogen gas.

\section{Calculation of uncertainties based on measurement uncertainty estimates}

Uncertainty dependence on individual parameters was calculated as the relative uncertainty dependence on the particular parameter. For example, the total uncertainty in nitrate molality $\left(\Delta \mathrm{m}_{\mathrm{NO} 3}\right)$ due to the measurement uncertainty in the amount of water is:

$\Delta \mathrm{m}_{\mathrm{NO} 3}($ water mass $)=\mathrm{m}_{\mathrm{NO} 3} *\left(\Delta\right.$ mass $_{\mathrm{H} 2 \mathrm{O}} /$ total mass of $\left.\mathrm{H}_{2} \mathrm{O}\right)$

The total uncertainty of the nitrate molality is dependent on the uncertainty in the amount of water and the amount added nitrate, and is calculated as the square root of the sum the individual certainties squared.

$\Delta \mathrm{m}_{\mathrm{NO} 3}($ total $)=\left[\left(\Delta \mathrm{m}_{\mathrm{NO} 3}(\text { water mass })\right)^{2}+\left(\Delta \mathrm{m}_{\mathrm{NO} 3}(\text { nitrate mass })\right)^{2}\right]^{0.5}$

The uncertainty of the product of two parameters is calculated as the product of the sum of the relative uncertainties of the individual parameters and the product of the two parameters. For the nitrate to chloride ratio, this is:

$$
\Delta\left(\mathrm{m}_{\mathrm{NO} 3} / \mathrm{m}_{\mathrm{Cl}}\right)=\left(\mathrm{m}_{\mathrm{NO} 3} / \mathrm{m}_{\mathrm{Cl}}\right) *\left(\Delta \mathrm{m}_{\mathrm{NO} 3}(\text { total })+\Delta \mathrm{m}_{\mathrm{Cl}}(\text { total })\right)
$$


Table 7. Calculated uncertainties of $\mathrm{NO}_{3}$ and $\mathrm{Cl}$ molality.

\begin{tabular}{|c|c|c|c|c|c|c|c|c|c|c|c|c|c|}
\hline & \multirow[t]{2}{*}{$\begin{array}{c}\mathrm{NO}_{3} \\
\text { (molal) }\end{array}$} & \multirow[t]{2}{*}{$\begin{array}{l}\text { Max Cl } \\
\text { (molal) }\end{array}$} & \multicolumn{5}{|c|}{ Solution composition } & \multirow[t]{2}{*}{$\begin{array}{c}\text { Uncertainty } \\
\text { in } \mathrm{NO}_{3} \text { molal } \\
\mathrm{H}_{2} \mathrm{O} \text { (mass) } \\
\text { dependence } \\
\end{array}$} & \multirow[t]{2}{*}{$\begin{array}{l}\text { Uncertainty } \\
\text { in } \mathrm{Cl} \text { molal } \\
\mathrm{H}_{2} \mathrm{O} \text { (mass) } \\
\text { dependence }\end{array}$} & \multirow[t]{2}{*}{$\begin{array}{c}\text { Uncertainty in } \\
\mathrm{NO}_{3} \text { molal } \\
\mathrm{NO}_{3} \text { (mass) } \\
\text { dependence }\end{array}$} & \multirow[t]{2}{*}{$\begin{array}{c}\text { Uncertainty } \\
\text { in } \mathrm{Cl} \text { molal } \\
\mathrm{Cl} \text { (mass) } \\
\text { dependence } \\
\end{array}$} & \multirow[t]{2}{*}{$\begin{array}{c}\Delta \mathrm{m}_{\mathrm{NO} 3} \text { (total) } \\
\text { Total } \\
\text { uncertainty in } \\
\mathrm{NO}_{3} \text { molal } \\
\end{array}$} & \multirow[t]{2}{*}{$\begin{array}{c}\Delta \mathrm{m}_{\mathrm{Cl}} \text { (total) } \\
\text { Total } \\
\text { uncertainty } \\
\text { in } \mathrm{Cl} \text { molal }\end{array}$} \\
\hline & & & $\begin{array}{l}\mathrm{H}_{2} \mathrm{O} \\
(\mathrm{kg})\end{array}$ & $\begin{array}{c}\mathrm{KNO}_{3} \\
(\mathrm{~g})\end{array}$ & $\begin{array}{c}\mathrm{NaNO}_{3} \\
(\mathrm{~g})\end{array}$ & $\begin{array}{c}\mathrm{KCl} \\
(\mathrm{g})\end{array}$ & $\begin{array}{c}\mathrm{NaCl} \\
(\mathrm{g})\end{array}$ & & & & & & \\
\hline \multirow{3}{*}{ 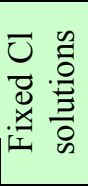 } & 0 & 9 & 0.5 & 0 & 0 & 167.8 & 131.5 & 0.0000 & 0.1800 & & 0.0090 & & 0.1802 \\
\hline & 3 & 9 & 0.5 & 75.9 & 63.9 & 167.8 & 131.5 & 0.0600 & 0.1800 & 0.0064 & 0.0090 & 0.0603 & 0.1802 \\
\hline & 6 & 8 & 0.4 & 121.2 & 102 & 119.3 & 93.5 & 0.1500 & 0.2000 & 0.0081 & 0.0113 & 0.1502 & 0.2003 \\
\hline \multirow{5}{*}{ 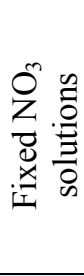 } & 42 & 4 & 0.25 & 530.8 & 446.2 & 37.2 & 29.2 & 1.6800 & 0.1600 & 0.0129 & 0.0181 & 1.6800 & 0.1610 \\
\hline & 50 & 4 & 0.25 & 631.9 & 531.3 & 37.2 & 29.2 & 2.0000 & 0.1600 & 0.0129 & 0.0181 & 2.0000 & 0.1610 \\
\hline & 75 & 3.5 & 0.15 & 568.7 & 478.1 & 22.4 & 13.2 & 5.0000 & 0.2333 & 0.0215 & 0.0295 & 5.0000 & 0.2352 \\
\hline & 85 & 4.5 & 0.15 & 644.6 & 541.8 & 28 & 17.6 & 5.6667 & 0.3000 & 0.0215 & 0.0296 & 5.6667 & 0.3015 \\
\hline & 100 & 4.5 & 0.12 & 606.7 & 509.9 & 22.5 & 14 & 8.3333 & 0.3750 & 0.0269 & 0.0370 & 8.3334 & 0.3768 \\
\hline \multirow{3}{*}{ 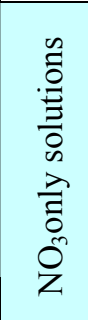 } & $111^{*}$ & & 0.12 & 673.8 & 566 & 0 & 0 & 9.2500 & 0.0000 & 0.0269 & & 9.2500 & \\
\hline & 75 & & 0.2 & 758.4 & 637.4 & 0 & 0 & 3.7500 & 0.0000 & 0.0161 & & 3.7500 & \\
\hline & 90 & & 0.2 & 910.1 & 764.9 & 0 & 0 & 4.5000 & 0.0000 & 0.0161 & & 4.5000 & \\
\hline
\end{tabular}


Table 8. Boiling point temperatures as a function of chloride and nitrate concentrations. Uncertainty of nitrate molality is listed and the uncertainty of temperature is fixed at $1.5^{\circ} \mathrm{C}$.

\begin{tabular}{|c|c|c|c|c|c|c|c|c|c|c|c|c|c|c|c|}
\hline \multirow{3}{*}{$\begin{array}{c}\mathrm{NO}_{3} \\
\text { (molality) }\end{array}$} & \multicolumn{14}{|c|}{ Boiling Points $\left({ }^{\circ} \mathrm{C}\right)$} & \multirow[b]{2}{*}{$\begin{array}{c}\Delta \mathrm{m}_{\mathrm{NO} 3} \text { (total) } \\
\text { Total } \\
\text { uncertainty in } \\
\mathrm{NO}_{3} \text { molal } \\
\end{array}$} \\
\hline & \multicolumn{14}{|c|}{$\mathrm{Cl}$ (molality } & \\
\hline & 0 & 0.5 & 1 & 1.5 & 2 & 2.5 & 3 & 3.5 & 4 & 4.5 & 5 & 6 & 8 & 9 & \\
\hline 0 & & & & & & & & & & & & & & 111.6 & \\
\hline 3 & & & & & & & & & & & & & & 115.0 & 0.0603 \\
\hline 6 & & & & & & & & & & & & & 116.5 & & \\
\hline 18 & & & & & & & & & & & & 115.0 & & & 0.4501 \\
\hline 25 & 118.7 & & 119.9 & & 120.3 & & 121.8 & & 121.8 & & 122.3 & & & & 0.8334 \\
\hline 42 & & & 128.0 & & & & & & & & & & & & 1.6800 \\
\hline 50 & 131.3 & & 133.1 & & 133.0 & & 134.9 & & 134.7 & & & & & & 2.0000 \\
\hline 75 & 141.3 & & 141.7 & 142.3 & 142.3 & 142.8 & 144.7 & 145.2 & 145.2 & & & & & & 5.0000 \\
\hline 85 & 145.0 & & & & 146.8 & 149.7 & 147.3 & & 147.1 & 148.0 & & & & & 5.6667 \\
\hline 100 & 150.5 & 150.2 & 152.4 & 154.5 & 155.2 & 156.3 & 155.2 & 158.3 & 160.3 & 160.9 & & & & & 8.3334 \\
\hline $111^{*}$ & 154.9 & & & & & & & & & & & & & & 9.2500 \\
\hline 30 & 121.2 & & & & & & & & & & & & & & 1.5001 \\
\hline 45 & 129.5 & & & & & & & & & & & & & & 2.2501 \\
\hline 60 & 136.4 & & & & & & & & & & & & & & 3.0000 \\
\hline 67.5 & 139.1 & & & & & & & & & & & & & & 3.3750 \\
\hline 75 & 143.6 & & & & & & & & & & & & & & 3.7500 \\
\hline 90 & 151.8 & & & & & & & & & & & & & & 4.5000 \\
\hline
\end{tabular}

* Note: That the calculated solution composition of $111 \mathrm{~m} \mathrm{NO}_{3}$ assumes that the starting solution contained $100 \mathrm{~m} \mathrm{NO}_{3}$ because it boiled at $150 \mathrm{C}$, similar to another $100 \mathrm{~m} \mathrm{NO}_{3}$ solution in this study. However, entries in the scientific notebook for this solution indicate a slightly lower concentration because a $100 \mathrm{~g}$ addition of $\mathrm{NaNO}_{3}$ was not entered. It is assumed that the omission was inadvertent. 
Table 9. Solution boiling point temperature dependence on total nitrate molal concentration with associated nitrate molal uncertainty. The uncertainty in the boiling point temperature is fixed at $1.5^{\circ} \mathrm{C}$.

\begin{tabular}{|r|r|r|}
\hline \multicolumn{1}{|c|}{$\begin{array}{r}\mathrm{NO}_{3} \\
\text { (molal) }\end{array}$} & $\begin{array}{c}\Delta \mathrm{m}_{\mathrm{NO}} \text { (total) } \\
\text { (total } \\
\text { Boint }\left({ }^{\circ} \mathrm{C}\right)\end{array}$ & $\begin{array}{c}\left.\mathrm{NO}_{3} \text { molal }\right) \\
\text { uncertainty in }\end{array}$ \\
\hline 25 & 118.7 & 0.83 \\
\hline 50 & 131.3 & 2.00 \\
\hline 75 & 141.3 & 5.00 \\
\hline 85 & 145 & 5.67 \\
\hline 100 & 150.5 & 8.33 \\
\hline $111^{*}$ & 154.9 & 9.25 \\
\hline 30 & 121.2 & 1.50 \\
\hline 45 & 129.5 & 2.25 \\
\hline 60 & 136.4 & 3.00 \\
\hline 67.5 & 139.1 & 3.38 \\
\hline 75 & 143.6 & 3.75 \\
\hline 90 & 151.8 & 4.50 \\
\hline
\end{tabular}

* Note: That the calculated solution composition of $111 \mathrm{~m} \mathrm{NO}_{3}$ assumes that the starting solution contained $100 \mathrm{~m} \mathrm{NO}_{3}$ because it boiled at $150 \mathrm{C}$, similar to another $100 \mathrm{~m} \mathrm{NO}_{3}$ solution in this study. However, entries in the scientific notebook for this solution indicate a slightly lower concentration because a $100 \mathrm{~g}$ addition of $\mathrm{NaNO}_{3}$ was not entered. It is assumed that the omission was inadvertent.

Table 10. Data for molal ratio of $\mathrm{NO}_{3}$ to $\mathrm{Cl}$ as a function of boiling point temperature. Determination of uncertainty is discussed in the text.

\begin{tabular}{|c|c|c|c|c|c|c|}
\hline $\begin{array}{c}\mathrm{NO}_{3} \\
\text { (molality) }\end{array}$ & $\begin{array}{c}\text { Max Cl } \\
\text { (molality) }\end{array}$ & $\begin{array}{c}\text { Boiling } \\
\text { Point }\left({ }^{\circ} \mathrm{C}\right) \\
\end{array}$ & $\begin{array}{c}\mathrm{NO}_{3} \\
\text { (molality) } \\
/ \mathrm{Cl} \\
\text { (molality) }\end{array}$ & $\begin{array}{l}\Delta \mathrm{m}_{\mathrm{NO} 3} \\
\text { (total) } \\
\text { Uncertainty } \\
\text { in } \mathrm{NO}_{3} \\
\text { molality }\end{array}$ & $\begin{array}{l}\Delta \mathrm{m}_{\mathrm{Cl}} \text { (total) } \\
\text { Uncertainty } \\
\text { in } \mathrm{Cl} \\
\text { molality }\end{array}$ & $\begin{array}{c}\text { Uncertainty in } \\
\mathrm{NO}_{3} / \mathrm{Cl}\end{array}$ \\
\hline & & & & & & \\
\hline 3 & 9 & 115 & 0.3 & 0.0603 & 0.1802 & 0.013 \\
\hline 6 & 8 & 116.5 & 0.8 & 0.1502 & 0.2003 & 0.038 \\
\hline 18 & 6 & 115 & 3.0 & 0.4501 & 0.1504 & 0.150 \\
\hline 25 & 5.5 & 122.9 & 4.5 & 0.8334 & 0.1839 & 0.304 \\
\hline 50 & 4 & 134.7 & 12.5 & 2.0000 & 0.1610 & 1.003 \\
\hline 75 & 3.5 & 145.2 & 21.4 & 5.0000 & 0.2352 & 2.869 \\
\hline 85 & 4.5 & 148 & 18.9 & 5.6667 & 0.3015 & 2.525 \\
\hline 100 & 4.5 & 160.9 & 22.2 & 8.3334 & 0.3768 & 3.713 \\
\hline
\end{tabular}


Table 11. Solubility limit for chloride in nitrate solutions with associated uncertainties in chloride and nitrate molal concentrations.

\begin{tabular}{|c|c|c|c|c|c|c|c|c|c|c|c|c|c|}
\hline & $\begin{array}{c}\mathrm{NO}_{3} \\
\text { (molal) }\end{array}$ & $\begin{array}{l}\text { Max Cl } \\
\text { (molal) }\end{array}$ & $\begin{array}{l}\text { Soluti } \\
\text { on } \\
\text { compo } \\
\text { sition }\end{array}$ & & & & & $\begin{array}{c}\text { Uncertainty in } \\
\mathrm{NO}_{3} \text { molal } \\
\mathrm{H}_{2} \mathrm{O} \text { (mass) } \\
\text { dependence }\end{array}$ & $\begin{array}{l}\text { Uncertainty in } \\
\mathrm{Cl} \text { molal } \mathrm{H}_{2} \mathrm{O} \\
\text { (mass) } \\
\text { dependence }\end{array}$ & $\begin{array}{c}\text { Uncertainty in } \\
\mathrm{NO}_{3} \text { molal } \\
\mathrm{NO}_{3} \text { (mass) } \\
\text { dependence }\end{array}$ & $\begin{array}{l}\text { Uncertainty in } \\
\mathrm{Cl} \text { molal } \mathrm{Cl} \\
\text { (mass) } \\
\text { dependence }\end{array}$ & $\begin{array}{c}\Delta \mathrm{m}_{\mathrm{NO} 3} \text { (total) } \\
\text { Total } \\
\text { uncertainty in } \\
\mathrm{NO}_{3} \text { molal }\end{array}$ & $\begin{array}{c}\Delta \mathrm{m}_{\mathrm{Cl}} \text { (total) } \\
\text { Total } \\
\text { uncertainty } \\
\text { in Cl molal }\end{array}$ \\
\hline & & & $\begin{array}{l}\mathrm{H}_{2} \mathrm{O} \\
(\mathrm{kg})\end{array}$ & $\begin{array}{c}\mathrm{KNO}_{3} \\
(\mathrm{~g})\end{array}$ & $\begin{array}{c}\mathrm{NaNO}_{3} \\
\text { (g) }\end{array}$ & $\begin{array}{c}\mathrm{KCl} \\
(\mathrm{g})\end{array}$ & $\begin{array}{l}\mathrm{NaCl} \\
(\mathrm{g})\end{array}$ & & & & & & \\
\hline \multirow{4}{*}{ 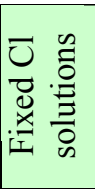 } & 0 & 9 & 0.5 & 0 & 0 & 167.8 & 131.5 & & 0.1800 & & 0.0090 & & 0.1802 \\
\hline & 3 & 9 & 0.5 & 75.9 & 63.9 & 167.8 & 131.5 & 0.0600 & 0.1800 & 0.0064 & 0.0090 & 0.0603 & 0.1802 \\
\hline & 6 & 8 & 0.4 & 121.2 & 102 & 119.3 & 93.5 & 0.1500 & 0.2000 & 0.0081 & 0.0113 & 0.1502 & 0.2003 \\
\hline & 18 & 6 & 0.4 & 363.9 & 306 & 89.5 & 70.1 & 0.4500 & 0.1500 & 0.0081 & 0.0113 & 0.4501 & 0.1504 \\
\hline \multirow{7}{*}{ 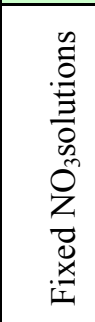 } & 25 & 5.5 & 0.3 & 379.2 & 318.8 & 66.6 & 43.5 & 0.8333 & 0.1833 & 0.0107 & 0.0150 & 0.8334 & 0.1839 \\
\hline & 42 & 4 & 0.25 & 530.8 & 446.2 & 37.2 & 29.2 & 1.6800 & 0.1600 & 0.0129 & 0.0181 & 1.6800 & 0.1610 \\
\hline & 50 & 4 & 0.25 & 631.9 & 531.3 & 37.2 & 29.2 & 2.0000 & 0.1600 & 0.0129 & 0.0181 & 2.0000 & 0.1610 \\
\hline & 75 & 3.5 & 0.15 & 568.7 & 478.1 & 22.4 & 13.2 & 5.0000 & 0.2333 & 0.0215 & 0.0295 & 5.0000 & 0.2352 \\
\hline & 85 & 4.5 & 0.15 & 644.6 & 541.8 & 28 & 17.6 & 5.6667 & 0.3000 & 0.0215 & 0.0296 & 5.6667 & 0.3015 \\
\hline & 100 & 4.5 & 0.12 & 606.7 & 509.9 & 22.5 & 14 & 8.3333 & 0.3750 & 0.0269 & 0.0370 & 8.3334 & 0.3768 \\
\hline & $111 *$ & & 0.12 & 673.8 & 566 & 0 & 0 & 9.2500 & 0.0000 & 0.0269 & & 9.2500 & \\
\hline
\end{tabular}

* Note: That the calculated solution composition of $111 \mathrm{~m} \mathrm{NO}_{3}$ assumes that the starting solution contained $100 \mathrm{~m} \mathrm{NO}_{3}$ because it boiled at $150 \mathrm{C}$, similar to another $100 \mathrm{~m} \mathrm{NO}_{3}$ solution in this study. However, entries in the scientific notebook for this solution indicate a slightly lower concentration because a $100 \mathrm{~g}$ addition of $\mathrm{NaNO}_{3}$ was not entered. It is assumed that the omission was inadvertent. 